Review Article

\title{
"Green" Synthesis of Metallic Nanoparticles by Sonoelectrochemical and Sonogalvanic Replacement Methods
}

\author{
Orest Kuntyi $\mathbb{D}^{1},{ }^{1}$ Galyna Zozulya $\mathbb{D}^{1},{ }^{1}$ and Andriy Kytsya $\mathbb{D}^{2}$ \\ ${ }^{1}$ Department of Chemistry and Technology of Inorganic Substances, Lviv Polytechnic National University, Bandery Str. 12, \\ Lviv 79013, Ukraine \\ ${ }^{2}$ Department of Physical Chemistry of Fossil Fuels of the Institute of Physical-Organic Chemistry and \\ Coal Chemistry Named After L. M. Lytvynenko of the National Academy of Sciences of Ukraine, Naukova Str. 3a, \\ Lviv 79060, Ukraine
}

Correspondence should be addressed to Andriy Kytsya; kytsya@nas.gov.ua

Received 21 July 2021; Revised 25 October 2021; Accepted 28 October 2021; Published 28 November 2021

Academic Editor: Valeria De Matteis

Copyright (C) 2021 Orest Kuntyi et al. This is an open access article distributed under the Creative Commons Attribution License, which permits unrestricted use, distribution, and reproduction in any medium, provided the original work is properly cited.

The main features of the "green" synthesis of metallic nanoparticles (MNPs) by the sonoelectrochemical methods are manufacturability, environmental friendliness, and the possibility of controlling the geometry of the forming particles. The electrochemical reduction technique allows efficiently designing the metal nanoparticles and provides the control of the content of components of bimetallic nanoparticles, as well as minimizing the number of precursors in working solutions. Due to the generation of turbulence, microjets, and shock waves, ultrasound increases mass transfer and formation of radicals in aqueous solutions and, accordingly, accelerates the processes of nucleation and growth of MNPs. Therefore, this hybrid method, which combines electrolysis and ultrasound, has attracted the interest of researchers in the last two decades as one of the most promising techniques. The present work presents a short analysis of the reference literature on sonoelectrochemical synthesis of metallic and bimetallic nanoparticles. The main factors influencing the geometry of nanoparticles and their size distribution are analyzed. The use of pulsed ultrasound and pulsed current supply during sonoelectrochemical synthesis is especially effective in designing MNPs. Emphasis is placed on the role of surfactants in the formation of MNPs and sacrificial anodes in providing the algorithm: "anodic dissolution-electrochemical reduction of metal-nucleation and formation of MNPs." It is noted that ultrasound allows synthesizing the MNPs and $\mathrm{M}_{1} \mathrm{M}_{2} \mathrm{NPs}$ during the galvanic replacement, and an analogy of the formation of nanoparticles by sonogalvanic replacement and sonoelectrochemical method is shown.

\section{Introduction}

Metal nanoparticles are widely used in biomedicine [1-5], biosensors $[4,6,7]$, catalysis $[1,8]$, and other fields. The nanoparticles of noble metals are the most studied in terms of the synthesis methods, as well as physicochemical and functional properties. AgNPs have a special place among all noble metals because they are characterized by high antimicrobial and anti-inflammatory activity and antitumor action. This gives the possibility of effectively applying them in the pharmaceutical and cosmetic industry; antibacterial, antiviral, and cancer therapy; tissue engineering; and other areas of biomedicine (Figure 1). Using the AuNPs [3] and PtNCs [4] for the treatment of cancer and bacterial diseases gave encouraging results in the last decade. In addition, AuNPs and PtNCs are considered as a new effective class of chemotherapeutics in the treatment of hematopoietic, lung, and hepatocellular malignant tumors.

Nanoparticles and nanoclusters of noble metals are effective in detecting the biological agents and therefore play a very important role in biomedicine. Thus, in [6], the advantages of plasmonic AgNPs, AuNPs, and PtNPs for the colorimetric sensing applications in drugs assays in pharmaceutical and biological samples are described. The use of gold nanoparticles in the chemiluminescence technique showed a high sensitivity for the detection of biological agents [7]. 


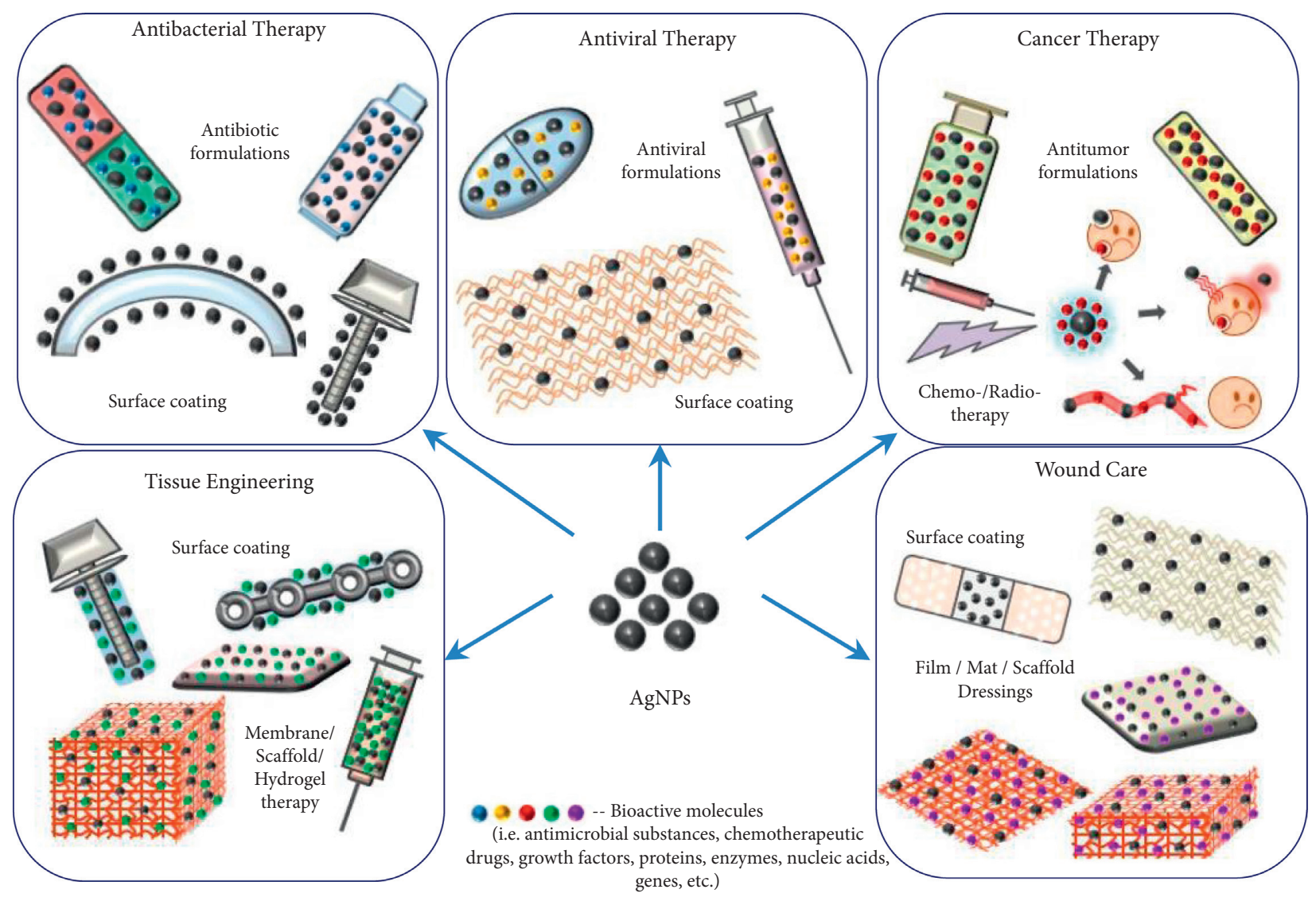

FIGURE 1: Applications of silver nanoparticles in biomedicine reproduced from [2] under the terms of the creative commons CC BY license.

Functional properties of MNPs, especially their biological activity, depend on both the nature of the metal and the geometry of the particles, that is, shape (sphere, rod, nanoshell, nanostar, etc.) and size (from 1 to $100-150 \mathrm{~nm}$ ) [1-7]. The geometry of MNPs determines their excellent biocompatibility and optical (caused by the surface plasmon resonance phenomenon) and catalytic properties (Figure 2). The different nanoeffects of the size and shape of metal nanoparticles mentioned above give the possibility of effectively using the MNPs in the biosensors.

Taking into account the requirement in such materials, as well as the dependence of their functional properties on the geometry of the particles and their composition, the choice of the correct method of MNPs' synthesis is very important. After all, in the triad, the method of synthesis $\longrightarrow$ geometry MNPs (and composition for $\left.M_{1} M_{2} N P s\right) \longrightarrow$ functional properties, the first component is decisive. The processes of obtaining of MNPs and $\mathrm{M}_{1} \mathrm{M}_{2} \mathrm{NPs}$ should correspond to the following basic modern criteria: (1) the control of the geometry and the composition (for binary) of nanoparticles; (2) "green" synthesis; and (3) manufacturability. Regardless of the method of synthesis (chemical [9, 10], electrochemical [11, 12], or physicochemical [13]), the controlled synthesis is the main condition for its effectiveness. "Green" synthesis is based on the use of nontoxic precursors, primarily reducing agents and surfactants of natural origin, such as plant extracts [9] and microorganisms [10]. "Green" synthesis also includes the electrochemical methods due to the cathodic reduction of metal ions and the use of nontoxic surfactants [11-13].

Manufacturability of synthesis of MNPs and $\mathrm{M}_{1} \mathrm{M}_{2} \mathrm{NPs}$ means, first of all, the maintenance of a high rate of processes. This is provided by electrochemical microplasma [13] and ultrasound [14-21]. Herein, we will consider ultrasound as one of the effective factors of MNPs engineering intensification.

In the last two decades, the interest in the use of ultrasound in nanomaterials preparation is greatly increased [14-21]. This is primarily caused by the complex effects of the ultrasonic field in aqueous solutions [22] such as (1) generation of turbulence, microjets, and shock waves; (2) increased mass transfer; and (3) formation of radicals in aqueous solutions. These effects have been successfully used in sonoelectrochemical deposition of nanostructured metal coatings [21, 23-28], preparation of composites [21, 29], sonoelectrochemical synthesis of colloidal solutions of metal nanoparticles $[15,17,20]$, and so on. The specificity of the synthesis of colloidal solutions of metal nanoparticles is due to the multifactorial and mutual influence of ultrasound and electrolysis on the formation of MNCs and MNPs in solutions $[17,19]$. Such complex impact of ultrasound and electrolysis makes it possible to provide a high rate of controlled synthesis of nanoparticles of metals of different nature (Table 1). Additionally, it should be noted that such technique is applicable for the synthesis of the metals characterized by positive values of the standard electrode 


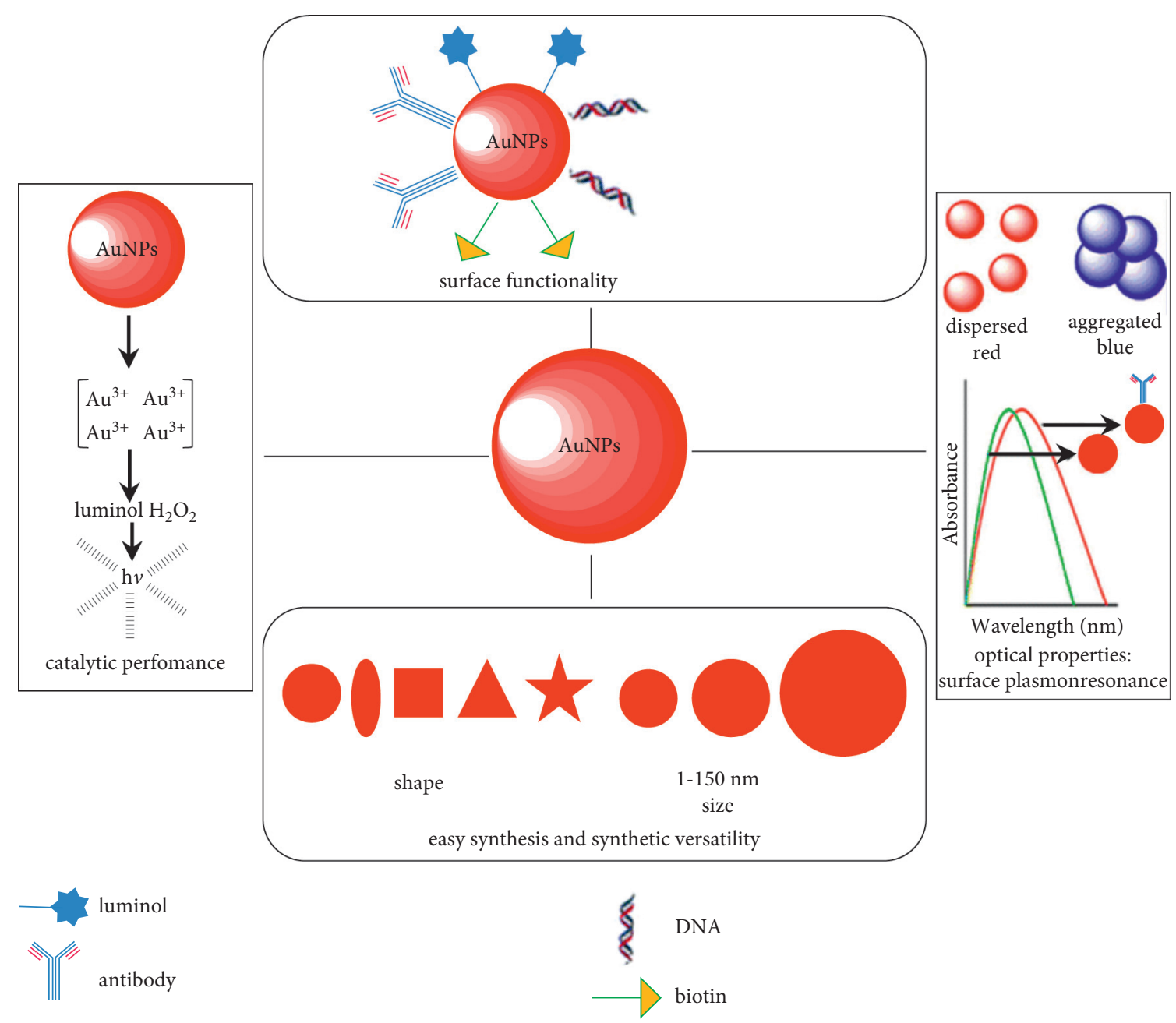

FIgURE 2: The unique attributes of AuNPs reproduced from [7] under the terms of the creative commons CC BY license.

potential (copper [30-33], noble metals [34-53]) and the metals characterized by negative values of $E^{0}$ (iron [54, 55], nickel [56], tungsten [57], magnesium [58], aluminum [59]).

Also, sonoelectrochemical techniques are effective in obtaining the bimetallic nanoparticles $\left(\mathrm{M}_{1} \mathrm{M}_{2} \mathrm{NPs}\right)$ and provide the controlled composition of binary systems. For example, such a method can be used for the synthesis of $\mathrm{M}_{1} \mathrm{M}_{2} \mathrm{NPs}$ containing the components characterized by close values of standard electrode potentials ( $\mathrm{Fe}, \mathrm{Co}, \mathrm{Ni}$ $[56,60-62])$ as well as nanosystems which significantly are differed in the values of $E^{0}$ ( $\mathrm{Fe}$ and $\mathrm{Cr}$ [63], $\mathrm{Cu}$ and $\mathrm{Ni}$ [64], $\mathrm{Cu}$ and $\mathrm{Pt}$ [65], $\mathrm{Pd}$ and $\mathrm{Fe}[66], \mathrm{Au}$ and $\mathrm{Ag}[66])$. Moreover, applying this technique, it is possible to control the size of nanoparticles during the synthesis (Table 2).

In nanomaterial science, galvanic replacement is used for obtaining the metal nanostructures on the surface of the sacrificial substrate [69-73] and submicron metal powders [74]. Sacrificial nanoscale metal is required for the synthesis of MNPs [75]. In [76-79], MNPs were synthesized using the sacrificial metal in the form of sheets, plates, or foils via the combining method of galvanic replacement and ultrasound in solutions containing the surfactants. Ultrasound is effective in the synthesis of $\mathrm{M}_{1} \mathrm{M}_{2} \mathrm{NPs}$ by galvanic replacement [80-86], and the sizes of obtained nanoparticles are in the range from a few nanometers up to $100 \mathrm{~nm}$ (Table 3). Sonogalvanic replacement also can be attributed to the sonoelectrochemical technique because the GR process proceeds via an electrochemical mechanism [69-72]. On the surface of the sacrificial metal, there are anode and cathode areas, where the electrons are "generated" due to electrochemical dissolution with the subsequent reduction of the metal ions and the MNPs formation. Therefore, the effect of the ultrasonic field on the electrochemical processes during galvanic replacement is similar to its effect during electrolysis.

An effect of "cavitation" is the main factor of ultrasound influencing the processes which occur (1) in the bulk of the electrolyte, (2) in the double electric layer, and (3) on the surface of the electrodes. All of these processes take place during the sonoelectrochemical synthesis of MNPs. The main factors contributing to the effective synthesis of MNPs are the following: 


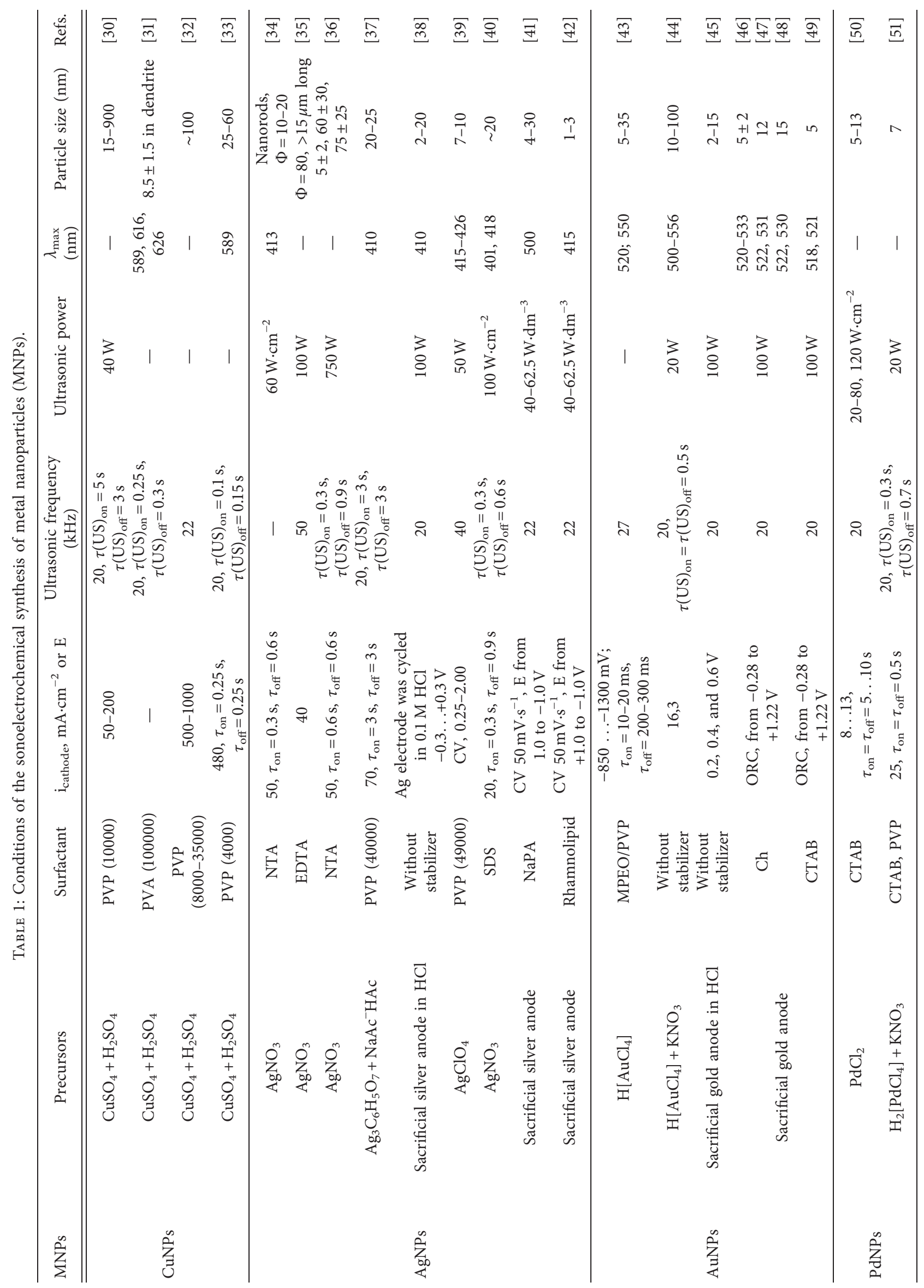




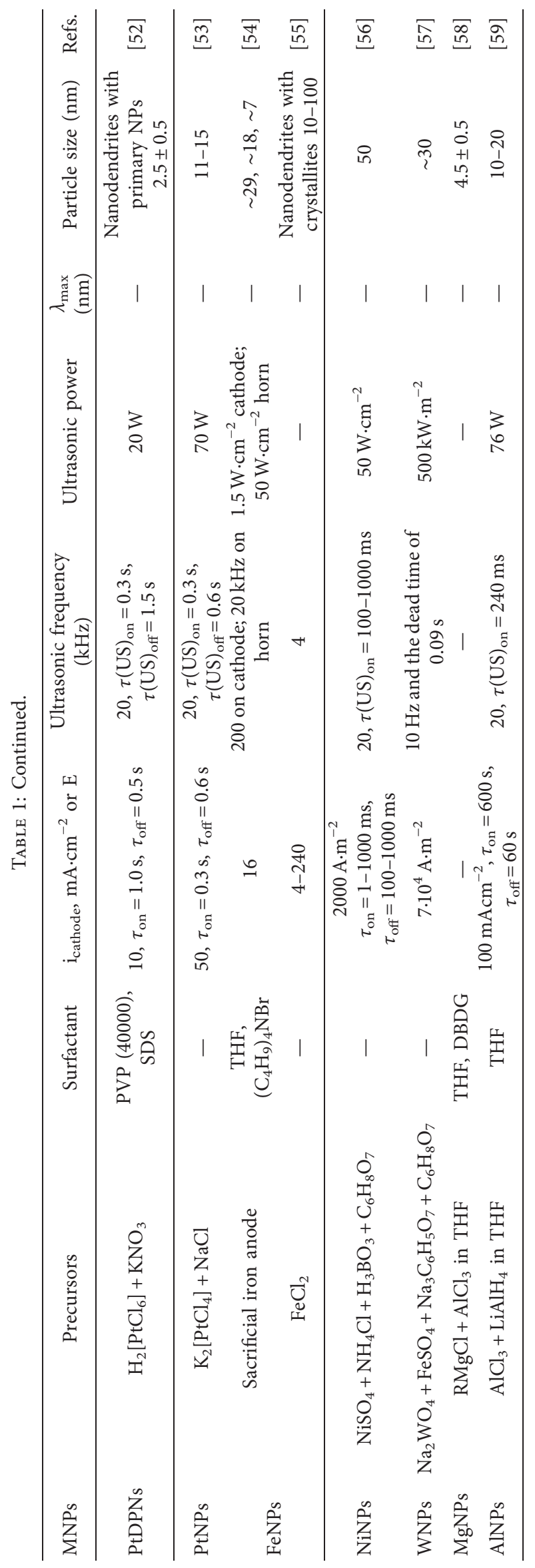




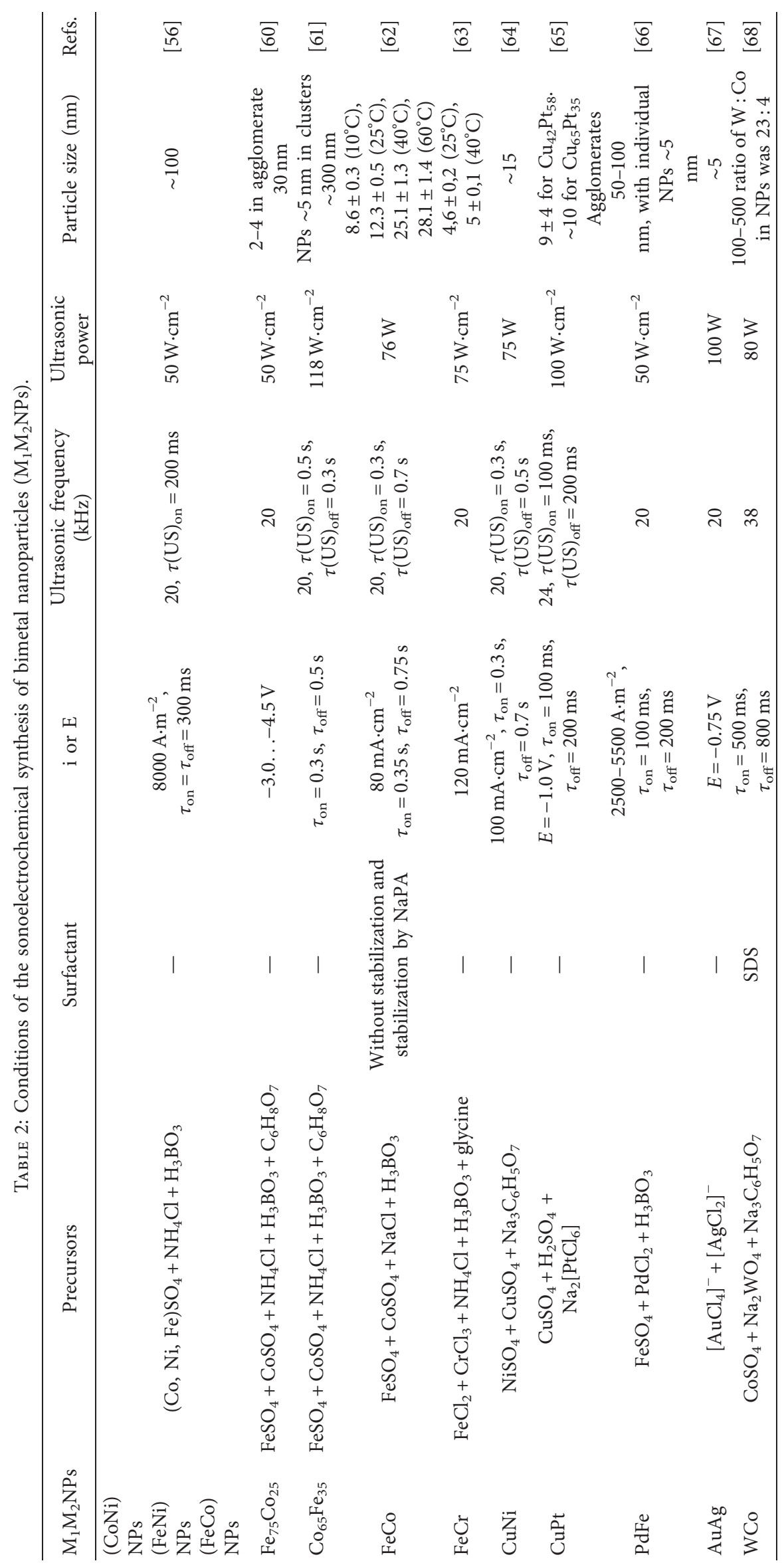


TABle 3: Conditions of the synthesis of metallic nanoparticles (MNPs, $\mathrm{M}_{1} \mathrm{M}_{2} \mathrm{NPs}$ ) by galvanic replacement in an ultrasonic field.

\begin{tabular}{|c|c|c|c|c|c|c|c|c|}
\hline Metallic nanoparticles & $\begin{array}{c}\text { Sacrificial } \\
\text { metal }\end{array}$ & Surfactant & $\begin{array}{c}\text { Precursor of } \\
\text { MNPs }\end{array}$ & $\begin{array}{l}\text { Ultrasonic } \\
\text { parameters }\end{array}$ & $t,{ }^{\circ} \mathrm{C}$ & $\begin{array}{c}\text { Time of } \\
\text { GR }\end{array}$ & $\begin{array}{c}\text { Size of NPs } \\
(\mathrm{nm})\end{array}$ & Refs. \\
\hline \multirow{5}{*}{$\begin{array}{l}\text { AgNPs, Ag nanodendrites } \\
\text { Nano-/microporous } \mathrm{Au} \\
\text { microsheets } \\
\text { AuNPs } \\
\text { PtNPs } \\
\text { RuNPs (Ag, } \mathrm{Cu}, \mathrm{Fe}, \mathrm{Co}, \mathrm{Ru}, \\
\text { and } \mathrm{Sn})\end{array}$} & $\mathrm{Cu}$ sheet & PVP & $\begin{array}{c}M N P s \\
\mathrm{AgNO}_{3}\end{array}$ & $40 \mathrm{kHz}$ & \multirow{5}{*}{$22 \pm 2$} & $10 \mathrm{~min}$ & 100 & {$[76]$} \\
\hline & Ag plate & - & $\mathrm{H}\left[\mathrm{AuCl}_{4}\right]$ & $135 \mathrm{~W}$ & & $10 \mathrm{~min}$ & $30-60$ & {$[77]$} \\
\hline & $\mathrm{Cu}$ foil & PVP & $\mathrm{H}\left[\mathrm{AuCl}_{4}\right]$ & $42 \mathrm{kHz}$ & & $5 \mathrm{~min}$ & 10 & {$[78]$} \\
\hline & Fe foil & PVP & $\mathrm{H}_{2}\left[\mathrm{PtCl}_{6}\right]$ & $42 \mathrm{kHz}$ & & $10 \mathrm{~min}$ & 10 & {$[78]$} \\
\hline & $\begin{array}{l}\text { Mg foil (Al, } \\
\text { Co) }\end{array}$ & PVP & $\mathrm{RuCl}_{3}$ & $42 \mathrm{kHz} 70 \mathrm{~W}$ & & $4 \mathrm{~min}$ & $3.1 \pm 0.9$ & {$[79]$} \\
\hline & & & $M_{1} M_{2} N P s$ & & & & & \\
\hline CuAgNPs & CuNPs & & $\mathrm{Ag}_{2} \mathrm{O}$ & $80 \mathrm{~W}$ & 30 & $5 \mathrm{~min}$ & $10-80$ & {$[80]$} \\
\hline $\mathrm{CuAgNPs}$ & CuNPs & & $\mathrm{Ag}_{2} \mathrm{O}$ & $100 \mathrm{~W} / \mathrm{cm}^{-2}$ & $22 \pm 2$ & - & $5-10$ & {$[81]$} \\
\hline Pd@CuNWs/MWCNTs-CH & $\mathrm{Cu}$ NWs & & $\mathrm{PdCl}_{2}$ & & $22 \pm 2$ & 1 hour & 150 & {$[82]$} \\
\hline Pd-AgNPs & Ag & & $\mathrm{PdCl}_{2}$ & $40 \mathrm{MHz}$ & 25 & $5 \mathrm{~min}$ & $2-3$ & {$[83]$} \\
\hline Ni@PtNPs & NiNPs & & $\operatorname{Pt}(\mathrm{acac})_{2}$ & $20 \mathrm{kHz}$ & $22 \pm 2$ & $3 \mathrm{hr}$ & $3-4$ & {$[84]$} \\
\hline PtCuNPs/NCNT & $\begin{array}{l}\text { CuNPs/ } \\
\text { NCNT }\end{array}$ & - & $\mathrm{Pt}\left(\mathrm{NO}_{3}\right)_{2}$ & $100 \mathrm{~W}, 20 \mathrm{kHz}$ & $22 \pm 2$ & $3 \mathrm{~min}$ & $\leq 5$ & {$[85]$} \\
\hline Pd@Pt/CNPs & $\mathrm{Pd}$ & SDS & $\mathrm{H}_{2}\left[\mathrm{PtCl}_{6}\right]$ & $20 \mathrm{kHz}$ & $25 \pm 1$ & $20 \mathrm{~min}$ & $3-5$ & [86] \\
\hline
\end{tabular}

(1). The destruction of cavitation bubbles causes high local temperatures and pressures. As a result, water is sonolized [14] and the radicals $\mathrm{H}^{*}$ and ${ }^{*} \mathrm{OH}$ (equation (1)) as well as the products of their interaction (equation (2)) are formed. In the presence of surfactants in the solution (which are commonly used as stabilizers of MNCs and MNPs), organic radicals R. (equation (3)) are also formed. Such radicals and products reduce the metal ions (equations (4)-(6)), primarily noble metals, which are characterized by high values of standard electrode potentials. Atoms $\mathrm{M}^{0}$ combine into nanoclusters and nanoparticles (equation (7)). Thus, a typical sonochemical synthesis of MNPs takes place in the bulk of electrolyte:

$$
\begin{gathered}
\mathrm{H}_{2} \mathrm{O} \longrightarrow \mathrm{H}+\mathrm{OH} \\
\mathrm{HO}+\mathrm{OH} \longrightarrow \mathrm{H}_{2} \mathrm{O}_{2} \\
\mathrm{RH}+\mathrm{OH}(\mathrm{H}) \longrightarrow \mathrm{R}+\mathrm{H}_{2} \mathrm{O}\left(\mathrm{H}_{2}\right) \\
\mathrm{M}^{\mathrm{n}+}+\mathrm{nH} \longrightarrow \mathrm{M}^{0}+\mathrm{nH}^{+} \\
\mathrm{M}^{\mathrm{n}+}+\mathrm{nR} \longrightarrow \mathrm{M}^{0}+\mathrm{nR}^{\prime}+\mathrm{nH}^{+} \\
\mathrm{M}^{\mathrm{n}+}+\mathrm{nH}_{2} \mathrm{O}_{2} \longrightarrow \mathrm{M}^{0}+\mathrm{nH}_{2} \mathrm{O}+\frac{\mathrm{n}}{2} * \mathrm{O}_{2} \\
\mathrm{mM}^{0} \longrightarrow \mathrm{M}_{\mathrm{m}}(\mathrm{MNCs}) \longrightarrow \cdots \longrightarrow \mathrm{MNPs}^{\longrightarrow}
\end{gathered}
$$

(2) In the ultrasound field, a thinning of the electrode diffusion layer thickness occurs. It causes a great enhancement in mass transport near the electrode, thereby accelerating the rate of the electrochemical reactions. At the same time, the values of currents of anodic dissolution of sacrificial metal
$[41,42,45,49,54]$ and cathode currents of metal ion reduction [41] increase significantly. Such a phenomenon leads to the increase in the rate of nucleation and, respectively, the formation of the smaller particles in comparison with the synthesis without US (Figure 3).

(3) The most described sonoelectrochemical synthesis of MNPs combines the pulsed electrolysis and pulsed ultrasound accordingly with the following algorithm [33, 34, 36]: 1. Time of electrolysis $\left(\tau_{\text {on }}\right) \longrightarrow 2$. Time of ultrasound $\left(\tau_{U S}\right) \longrightarrow 3$. Pause of electrolysis and ultrasound ( $\left.\tau_{\text {off }}\right)$ (Figure 4$)$.

Ultrasound periodically performs the function of "shaking" of MNPs from the cathode surface after their deposition during the current pulse. Moreover, the ultrasonic horn is periodically used as the vibrating working electrode, that is, as "sonoelectrode" in a three-electrode setup $[17,34]$. During the pause of electrolysis ( $\left.\tau_{\text {off }}\right)$, in addition to the "shaking" of MNPs, the diffusion of metal ions to the cathode occurs (Figure 5). It was noted that the time of the ultrasound ( $\left.\tau_{\mathrm{US}}\right)$ is a period of peculiar ablation of metallic nuclei from the cathodic surface [53].

Sonoelectrochemical synthesis of metallic nanoparticles as a hybrid technique significantly predominates the sonochemical and electrochemical methods in terms of the rate of the process. In addition, it is controllable and allows obtaining mono- and bimetallic nanoparticles of a wide range of sizes from 2 to $100 \mathrm{~nm}$ (Tables 1 and 2). However, the techniques described in the references differ in the constructions of sonoelectrochemical cells, power, and frequency of ultrasound applied and the constructions of current supply and modes of electrolysis. Therefore, the purpose of this review is to offer a systematic analysis of the references on sonoelectrochemical synthesis of metallic nanoparticles over the past two decades and provide the guidelines of operating conditions to maximize the beneficial effects. 


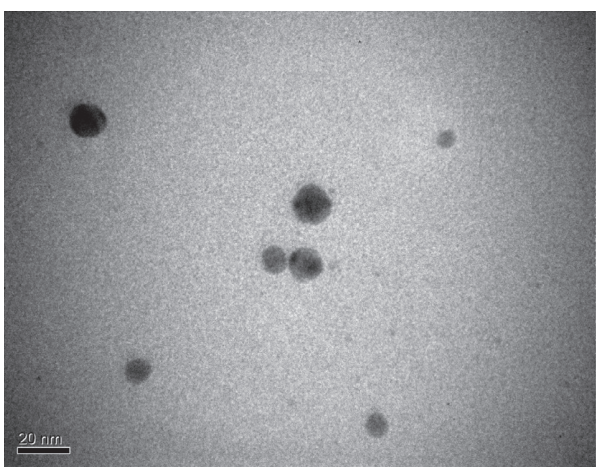

(a)

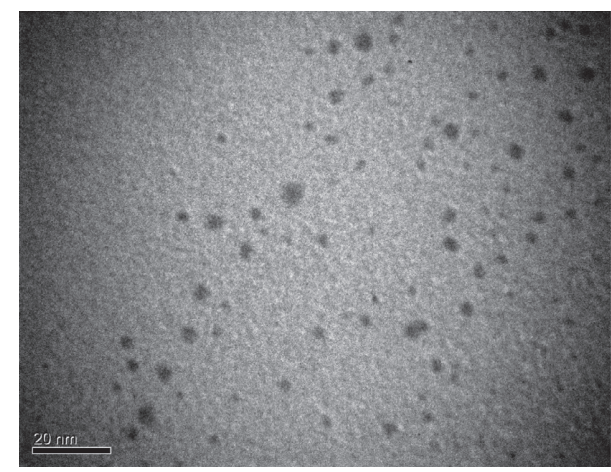

(b)

FIGURE 3: TEM images of AgNPs synthesized in solution NaPA (5 g L-1) by cyclic voltammetric (during 20 cycles) without ultrasonic field (a) and in the ultrasonic field (b), $t=20^{\circ} \mathrm{C}$. Reproduced from [41] under the terms of the Creative Commons CC BY license.

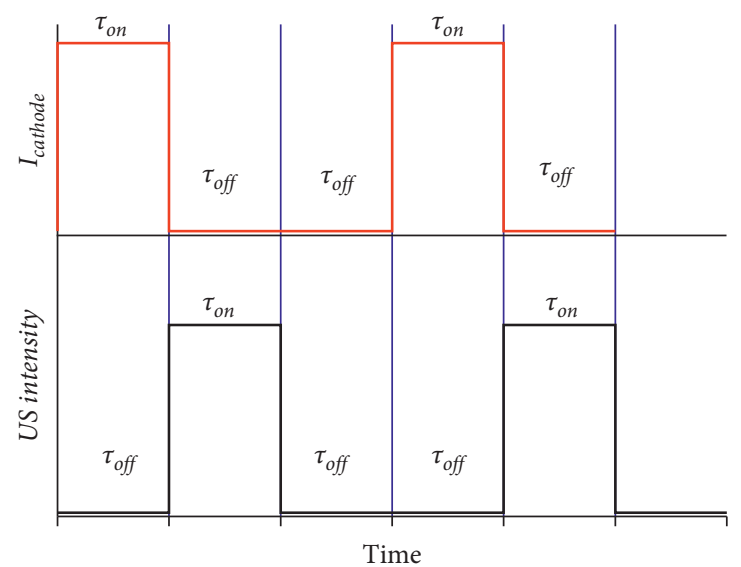

FIGURE 4: Scheme of pulsed current supply and ultrasound during sonoelectrochemical synthesis of MNPs.

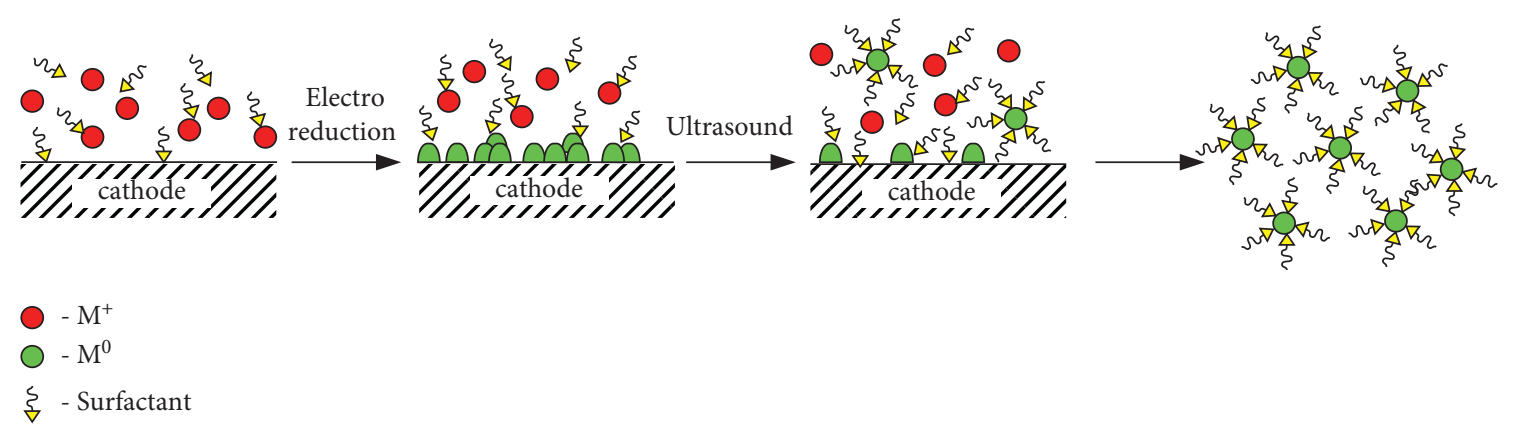

FIGURE 5: Scheme of MNPs formation by pulsed current supply and pulsed ultrasound in solution with surfactant.

\section{Sonoelectrochemical Synthesis of Metallic Nanoparticles}

The vast majority of reported methods of sonoelectrochemical synthesis of MNPs and $\mathrm{M}_{1} \mathrm{M}_{2} \mathrm{NPs}$ are based on the use of corresponding simple or complex salts as the precursors of metal ions (Tables 1 and 2). Only in some references, the source of metal ions is sacrificial anodes; for example, silver electrodes were applied in solutions of $\mathrm{HCl}$
[38] and NaPA [41] for the synthesis of AgNPs. Most of the sonoelectrochemical syntheses of metallic nanoparticles are based on the use of surfactants to stabilize of MNPs and $\mathrm{M}_{1} \mathrm{M}_{2} \mathrm{NPs}$. Usually the polymeric substances containing different functional groups are used as the surfactants, for example, PVP [32, 33, 37, 39, 43, 52], PVA [31], NaPA $[41,62]$, and rhamnolipid [42]. In some cases, the role of the surfactant can play the molecules of the solvent, for example, THF $[54,58,59]$. 
2.1. Sonoelectrochemical Synthesis of MNPs. MNPs of the wide range of the standard electrode potentials values (Table 1) can be obtained using the sonoelectrochemical technique. In the presence of surfactants in solutions, metal ions of simple salts exist in the form of complexes. Thus, in PVP solutions, $\mathrm{Cu}(\mathrm{II})$ [33] or $\mathrm{Ag}$ (I) ions form complexes due to electron-donor atoms of the oxygen and nitrogen of the pyrrolidone fragment of the polymer molecule of PVP, which leads to the formation of a bond via the donor-acceptor mechanism: $\mathrm{O}: \longrightarrow \square \mathrm{Ag}(+)$ and (or) $\mathrm{N}: \longrightarrow \square \mathrm{Ag}(+)$. Therefore, in PVP solution, the complexes of $\mathrm{Ag}(\mathrm{I})$ localized in the polymer chain with a bidentate ligand are formed (Figure 6(a)). Complexes formed in NaPA solutions are presented in Figure 6(b).

2.1.1. CuNPs. The main difficulty of sonoelectrochemical synthesis of CuNPs is the tendency for easy oxidation of copper in aqueous solutions. Even an inert atmosphere does not prevent the formation of $\mathrm{CuO}$ because, in aqueous solutions hydroxyl radicals (equation (1)), $\mathrm{H}_{2} \mathrm{O}_{2}$ (equation (2)) and $\mathrm{O}_{2}$ (equation (6)) are formed due to sonolysis and oxidize CuNPs. Therefore surfactants (PVP [30, 32, 33] or PVA [31]) are used as a capping agent. In addition, electron-donor atoms of the oxygen and nitrogen of the pyrrolidone fragment of the polymer molecule of PVP form bonds with $\mathrm{Cu}^{2+}$ ions via donor-acceptor mechanism: O: $\longrightarrow \mathrm{Cu}^{2+}$ and (or) N: $\longrightarrow \mathrm{Cu}^{2+}[33]$. Therefore, PVP-Cu ${ }^{2+}$ complexes are formed, which are transformed into an intermediate neutral PVP- $\mathrm{Cu}^{0}$ complex, and the surface PVP-CuNPs complex is formed after the cathodic reduction of $\mathrm{Cu}^{2+}$ to $\mathrm{Cu}^{0}$. Synthesis of CuNPs is performed by well-known pulsed sonoelectrochemical method in accordance with the following protocol: electrolysis $\left(\tau_{o n}\right) \longrightarrow$ ultrasound $\left(\tau_{U S}\right) \longrightarrow$ pause of electrolysis and ultrasound $\left(\tau_{o f f}\right)$. The size of nanoparticles depends on the following main factors: sonication power, current density, temperature, experiment duration. In [30], an optimal range of values for the sonication power was shown. Thus, at $20 \mathrm{~W}$, complete separation of precipitate from the sonoelectrode is not provided, but ultrasonic power more than $90 \mathrm{~W}$ causes a significant increase in the size of CuNPs. Such phenomenon is due to overheating of the solution, but the increase in temperature is undesirable for obtaining small nanoparticles. For example, at sonoelectrochemical synthesis at $15^{\circ} \mathrm{C}$, CuNPs with an average size of $17 \mathrm{~nm}$ are formed, while at $50^{\circ} \mathrm{C}$, the size of particles is increased to $62 \mathrm{~nm}$ [33]. Therefore, ultrasonic power should be sufficient to ensure complete removal of nanoparticle sediment from the sonoelectrode but should not be too high to cause the overheating of solution. The influence of current density is also significant. A decrease in the size of CuNPs with decreasing the value of $i_{\text {cathode }}$ was noted; for example, the mean diameter of CuNPs reduced from $\sim 800 \mathrm{~nm}$ to $\sim 45 \mathrm{~nm}$ with decreasing $i_{\text {cathode }}$ from $760 \mathrm{~mA} \cdot \mathrm{cm}^{-2}$ to $240 \mathrm{~mA} \cdot \mathrm{cm}^{-2}$ [30]. The tendency to decrease the size of nanoparticles with increasing $i_{\text {cathode }}$ is also shown by [33]: at 55,70 , and $100 \mathrm{~mA} \cdot \mathrm{cm}^{-2}$, CuNPs with mean diameters of 29,24 , and $10 \mathrm{~nm}$, respectively, were obtained.
2.1.2. AgNPs. Sonoelectrochemical synthesis of AgNPs is carried out mainly in solutions containing surfactants. Most of reported surfactants are ligands, so the reduction from complexes such as $\operatorname{Ag}(\mathrm{I})-\mathrm{NTA}[34,36], \mathrm{Ag}(\mathrm{I})$-EDTA [35], $\mathrm{Ag}(\mathrm{I})-\mathrm{PVP}[37,39], \mathrm{Ag}(\mathrm{I})-\mathrm{PA}^{-}[41]$ to $\mathrm{Ag}(0)$ occurs. In the formation of nanoclusters and nanoparticles, the surfactants participate in the formation of surface complexes and, accordingly, play the role of AgNPs stabilizers. The following three variants of sonoelectrochemical synthesis of AgNPs are described in references: (1) the combination of pulsed electrolysis and pulsed ultrasound [36, 37, 40]; (2) the combination of pulsed [34] or cyclic [39, 41] electrolysis and stationary ultrasound; and (3) synthesis at constant values of the electrode potential or current density and constant values of ultrasound parameters [35, 39]. Precursors of silver are mainly the soluble salts, such as $\mathrm{AgNO}_{3}[34,36,40]$, $\mathrm{Ag}_{3} \mathrm{C}_{6} \mathrm{H}_{5} \mathrm{O}_{7}$ [37], and $\mathrm{AgClO}_{4}$ [39]. The use of sacrificial silver anode is promising to ensure a stable concentration of $\mathrm{Ag}(\mathrm{I})$ ions and, accordingly, the efficacy of sonoelectrochemical synthesis of AgNPs [37, 41]. It was reported [41] that, in solutions of polymeric surfactant (polyacrylate), the currents of anodic dissolution of silver with the formation of complexes $\left[\left(\mathrm{Ag}^{+}\right)_{\mathrm{m}} \mathrm{PA}\right]^{(\mathrm{n}-\mathrm{m})}$ (equation (8)) are commensurate with the cathodic currents of reduction reaction (equation (9)). Also, taking into account the reactions (1-5) caused by ultrasound, the algorithm "anodic dissolution-reduction of $\mathrm{Ag}(\mathrm{I})$-nucleation and formation of $A g N P s "$ is provided. This causes the low concentrations of $\left[\left(\mathrm{Ag}^{+}\right)_{\mathrm{m}} \mathrm{PA}\right]^{(\mathrm{n}-\mathrm{m})}$ complex ions in solution, which creates favorable conditions for the formation of small-sized silver nanoparticles (Figure 7):

$$
\begin{array}{r}
\mathrm{mAg}+\mathrm{PA}^{\mathrm{n}-} \longrightarrow\left[\left(\mathrm{Ag}^{+}\right) \mathrm{mPA}\right]^{(\mathrm{n}-\mathrm{m})}+\mathrm{me} \\
{\left[\left(\mathrm{Ag}^{+}\right) \mathrm{mPA}\right]^{(\mathrm{n}-\mathrm{m})-}+\mathrm{me} \longrightarrow\left[\left(\mathrm{Ag}^{0}\right) \mathrm{mPA}\right]^{\mathrm{n}-}}
\end{array}
$$

2.1.3. AuNPs. Sonoelectrochemical synthesis of AuNPs is carried out mainly in solutions containing the surfactants $[43,46-49]$ and in some cases without them [44, 45]. AuNPs synthesized without surfactants may be used in biomedicine and catalysis. Sacrificial gold anodes also are used [45-49].

A study of sonoelectrochemical synthesis of AuNPs without a stabilizer [44] demonstrated that the current density in a wide range of values has little effect on the UVVis spectra of colloid solutions and the geometry of nanoparticles. However, the effect of the current pulse duration is significant, with the increase in which there is a tendency to increase the size of nanoparticles (Figure 8).

In another study [47], a method of sonoelectrochemical synthesis of AuNPs by the dissolution of $\mathrm{Au}$ substrates via electrochemical treatments of "oxidation-reduction" cycles with subsequent sonoelectrochemical reductions of $\mathrm{Au}$-ions to synthesize $\mathrm{Ch} / \mathrm{Au}$ nanocomposite was proposed. Such $\mathrm{Ch} /$ $\mathrm{Au}$ nanocomposite can be destroyed in the ultrasonic field, and AuNPs are formed. Therefore, chitosan was included as a polymeric surfactant performing the function of a matrix during synthesis. The overall process can be represented by 
<smiles>CC(C)CC(N1CCCC1=O)C(C)(C)C</smiles>

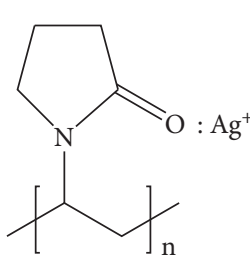

(a)

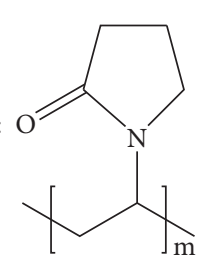<smiles>CC(C)(C)CC(C(=O)[OH2+])C(C)(C)C(C)(C)CC([InH])C(=O)[OH2+]</smiles>

(b)

FIgURE 6: Scheme of formation of complexes of $\mathrm{Ag}(+)$ ions with PVP (a) or $\mathrm{PA}^{-}$(b).

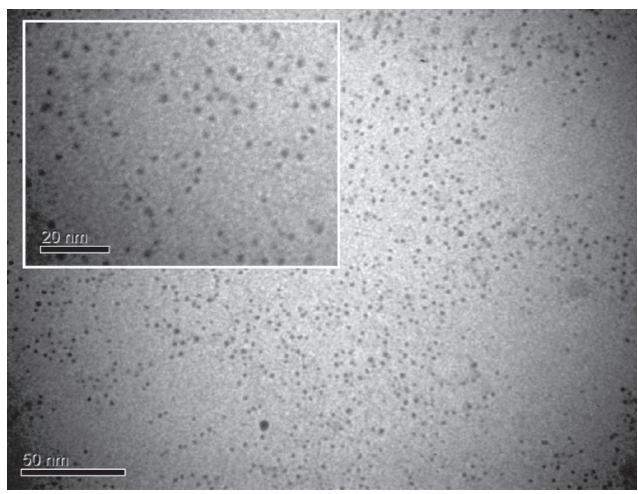

(a)

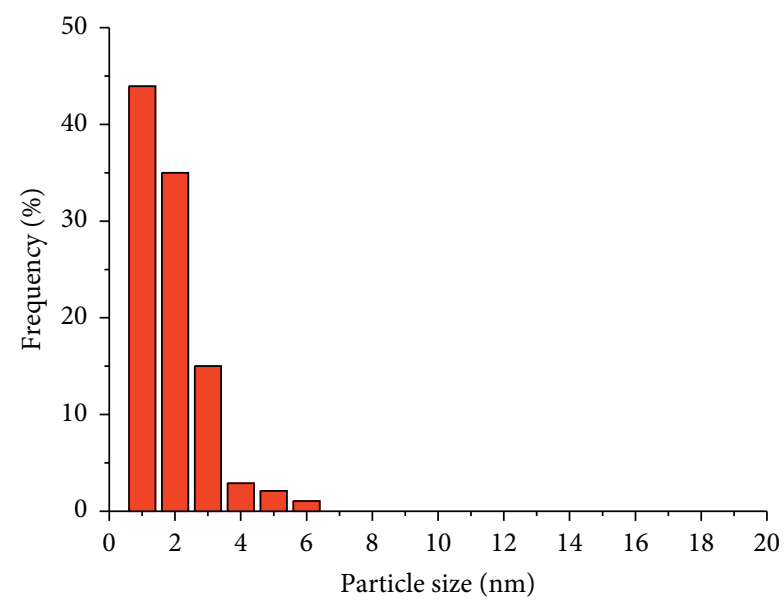

(b)

Figure 7: TEM images (a) and the size distribution histograms (b) of AgNPs, synthesized in RL solution $(2 \mathrm{~g} / \mathrm{L})$ at $40 \mathrm{cycles}, t=20^{\circ} \mathrm{C}$. Reproduced from [42] under the terms of the Creative Commons CC BY license.

the algorithm: "gold polycrystalline $+\mathrm{Cl}^{-}+\mathrm{Ch} \quad \mathrm{ORC} \longrightarrow \mathrm{Ch}-$ $\left[\mathrm{AuCl}_{4}\right]^{-}$sonoelectrochem $\longrightarrow \mathrm{Ch}-\mathrm{AuNPs}$ sonification $\longrightarrow A u N P s$," which makes it possible to obtain the nanoparticles with the size of $\sim 12 \mathrm{~nm}$ and narrow size distribution. So, ultrasound performs a dual function in the proposed method of synthesis: the first is the promotion of the AuNPs formation during the electrochemical reduction of $\mathrm{Ch}-$ $\left[\mathrm{AuCl}_{4}\right]^{-}$and the second is the destruction of the formed Ch-AuNPs nanocomposites.

2.1.4. PdNPs and PtNPs. In [50], it was shown that controlled sonoelectrochemical synthesis of PdNPs is affected by the following parameters, namely, current density, power of ultrasound, and surfactant concentration. It was shown that, with increasing the current density, the size of nanoparticles is decreased. Specifically, at $\mathrm{i}_{\text {cathode }}$ equal to 8 and $13 \mathrm{~mA} \cdot \mathrm{cm}^{-2}$, the diameters of formed PdNPs were equal to 10 and $5 \mathrm{~nm}$, respectively. The optimal range of ultrasound power also has been determined. Under intensities lower than $20 \mathrm{~W} \cdot \mathrm{cm}^{-2}$, the particles were irregularly shaped and ere agglomerated due to insufficient ultrasound energy for effective ablation of PdNPs from the cathode surface. Hence, some of them continued to grow in the next cycle of cathodic reduction. The power range from 20 to $80 \mathrm{~W} \cdot \mathrm{cm}^{-2}$ was effective for obtaining PdNPs with a diameter from 5 to $10 \mathrm{~nm}$. Using the intensities above $120 \mathrm{~W} \cdot \mathrm{cm}^{-2}$ was also problematic due to the local overheating of the cathode surface (up to $90^{\circ} \mathrm{C}$ ), which causes the agglomeration of nanoparticles. Also, it has been shown that a surfactant should be present to prevent the agglomeration of nanoparticles. Another study [51] also revealed a similar trend to PdNPs size dependence on the value of current density.

A significant feature of sonoelectrochemical synthesis [52] is the formation of 3D dendritic structures of platinum with a diameter of about $30 \mathrm{~nm}$. The authors showed the possibility of controlled influence of synthesis parameters on the size and morphology of nanoparticles. As specific example, it was reported that, at $5 \mathrm{~mA} \cdot \mathrm{cm}^{-2}$, monodispersed PtDPNs with size of $6 \mathrm{~nm}$ were formed; at $20 \mathrm{~mA} \cdot \mathrm{cm}^{-2}$, heterogeneous PtDPNs with broad variation in size were formed; and finally at $40 \mathrm{~mA} \cdot \mathrm{cm}^{-2}$, agglomeration of DPNs was observed. Another study [53] emphasized the importance of optimization of the duration of the electrochemical pulse for obtaining the desired size of PtPNs. It was shown that an increase in $\tau_{\text {on }}$ leads to an increase in the size of nanoparticles and also causes difficulties in PtPNs ablation from the surface of the sonoelectrode.

2.1.5. FeNPs. In [54], the synthesis of FeNPs in tetrahydrofuran and atmosphere of argon was described, and the molecules of solvent $\left[\left(\mathrm{C}_{4} \mathrm{H}_{9}\right)_{4} \mathrm{~N}\right]$ play the role of the nanoparticles stabilizer. The size of FeNPs was regulated by the frequency of ultrasound during the electrochemical synthesis. It was found that, under the action of ultrasonic of 


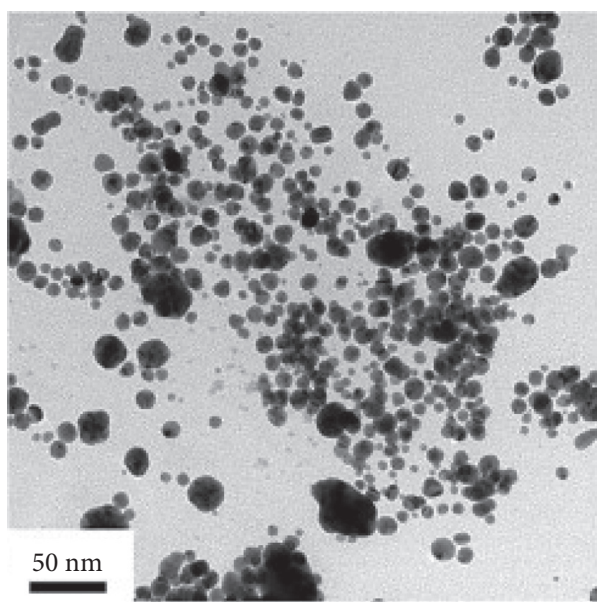

(a)

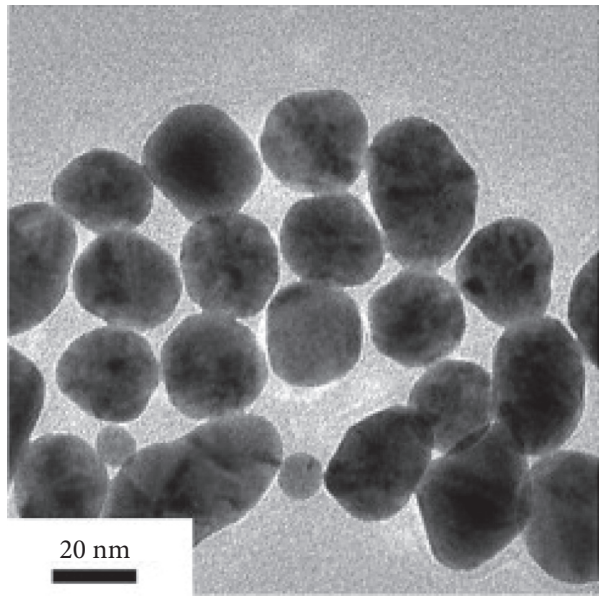

(c)

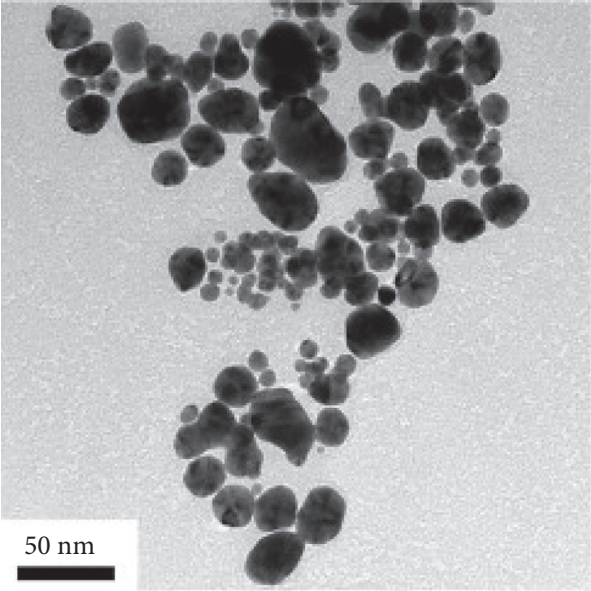

(b)

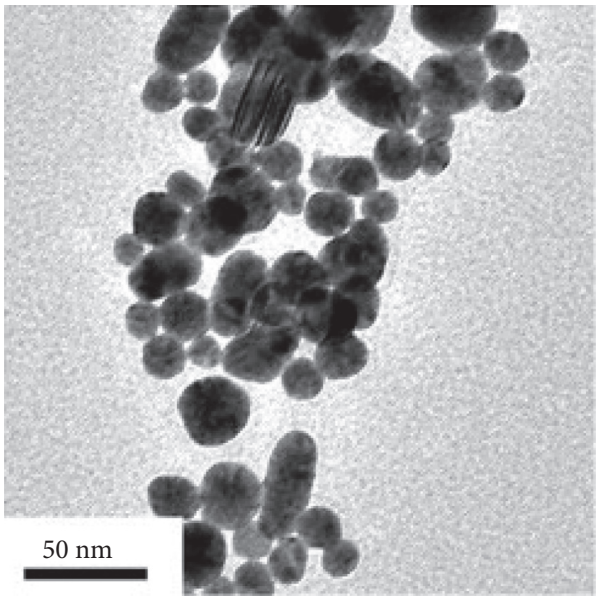

(d)

FIGURE 8: TEM images of the Au NPs synthesized by sonoelectrochemical method at different pulse times $\left(\tau_{\text {current }} / \tau_{\text {sono }}\right)$. (a) $0.3 \mathrm{~s} / 0.3 \mathrm{~s}$. (b) $0.4 \mathrm{~s} / 0.4 \mathrm{~s}$. (c) $0.5 \mathrm{~s} / 0.5 \mathrm{~s}$. (d) $1.0 \mathrm{~s} / 1.0 \mathrm{~s}$. Reproduced from [44] under the terms of the Creative Commons CC BY license.

$200 \mathrm{kHz}$ and $20 \mathrm{kHz}$ and simultaneous action of 200 and $20 \mathrm{kHz}$, the average sizes of the obtained iron particle were 29,18 , and $7 \mathrm{~nm}$, respectively. The authors explain this as in the case of only low-frequency ultrasound at $20 \mathrm{kHz}$, an area of intense cavitation in the interelectrode space is formed. The cavitation effect is continued after the shaking of FeNPs from the surface of the sonocathode also in the volume of the solution, and this promotes the formation of smaller nanoparticles. At high frequencies $(200 \mathrm{kHz})$, the cavitation effect occurs mainly on the cathode surface. Moreover, simultaneous use of low- and high-frequency ultrasonic fields can, in addition to cavitation, create both microflows of significant intensity and large-scale ultrasonic flows. This simultaneous action of low and high frequency ultrasonic fields increases the efficiency of the ultrasonic action in the liquid and leads to decreasing of the size of formed FeNPs.

In aqueous solutions, the sonoelectrochemical synthesis of FeNPs is based on the simultaneous cathodic reduction of $\mathrm{Fe}(+2)$ and $\mathrm{H}(+)$, where the formed $\mathrm{H}_{2}$ bubbles, in addition to providing a reducing atmosphere, affect the formation of nanoparticles [55].
2.1.6. WNPs. Tungsten cannot be reduced in aqueous solutions, and hence the method of pulsed sonoelectrochemical coprecipitation of $\mathrm{Fe}$ and $\mathrm{W}$ can be used [57]. The process occurs due to the catalysis of reduction of tungsten (equation (11)) by the formed iron (equation (10)) with the formation of nanoparticles of FeWNPs. After ultrasonic ablation of particles from the cathode surface, FeWNPs in acidic solution are converted into WNPs due to the dissolution of iron:

$$
\begin{aligned}
& {\left[\mathrm{FeC}_{6} \mathrm{H}_{5} \mathrm{O}_{7}\right]^{-}+2 \mathrm{e} \longrightarrow \mathrm{Fe}+\mathrm{C}_{6} \mathrm{H}_{5} \mathrm{O}_{7}^{3-}} \\
& {\left[\mathrm{WO}_{2} \mathrm{C}_{6} \mathrm{H}_{5} \mathrm{O}_{7}\right]^{-}+4 \mathrm{H}^{+}+6 \mathrm{e} \longrightarrow \mathrm{W}+\mathrm{C}_{6} \mathrm{H}_{5} \mathrm{O}_{7}^{3-}+2 \mathrm{H}_{2} \mathrm{O}}
\end{aligned}
$$

2.1.7. MgNPs and AlNPs. Magnesium and aluminum are metals that can be reduced only in a nonaqueous medium due to their standard electrode potentials being equal to $-2.356 \mathrm{~V}$ and $-1.66 \mathrm{~V}$, respectively. Therefore, the synthesis of MgNPs [58] and AlNPs [59] can be performed by the sonoelectrochemical method in an organic aprotic solvent 
(THF), which, in addition to the nonaqueous medium, acts as a stabilizer. Due to the donor-acceptor binding $\left(\mathrm{CH}_{2}\right)_{4} \mathrm{O}$ : $\longrightarrow \mathrm{Mg}(\mathrm{Al})$, molecules of THF form surface complexes. This provides "encapsulation" of MNPs, preventing their agglomeration. The main function of the pulsating ultrasound was to shake the metal nanoparticles deposited on the cathode. Taking into account the requirement in MgNPs and AlNPs in the production of hydride materials based on these metals, the proposed techniques are considered suitable for use on a technological scale $[58,59]$.

2.2. Sonoelectrochemical Synthesis of M1M2NPs. In the case of composites, the coreduction of $\mathrm{M}_{1}$ and $\mathrm{M}_{2}$ is performed from solutions containing ions of two corresponding metals (Table 2). For metals which are a little differed in the values of standard electrode potentials ( $\mathrm{Fe}, \mathrm{Co}, \mathrm{Ni})$, the controlled content of components in $\mathrm{M}_{1} \mathrm{M}_{2} \mathrm{NPs}$ can be decided by controlling the concentrations of salts [56, 60-62]. Thus, sonoelectrochemical synthesis from $\mathrm{FeSO}_{4}+\mathrm{CoSO}_{4}$ solutions of different concentrations makes it possible to obtain $\mathrm{Fe}_{75} \mathrm{Co}_{25} \mathrm{NPs}$ [60], $\mathrm{Co}_{65} \mathrm{Fe}_{35}$ [61], $\mathrm{FeCo}_{(1-2)} \mathrm{NPs}$ [62], and $\mathrm{FeCo}_{(1-4)} \mathrm{NPs}$ [62]. In the case of metals with large differences in the values of $\Delta E^{0}(\mathrm{Cu}$ and $\mathrm{Ni}$ [64], $\mathrm{Cu}$ and $\mathrm{Pt}$ [65], $\mathrm{Pd}$ and $\mathrm{Fe}[66])$, an advanced reduction of more electrodegradable metal is observed. For example, during the sonoelectrochemical synthesis of $\mathrm{Cu}-\mathrm{Pt}$ nanopowders [65], part of the reduced copper acts as a sacrificial metal to reduce platinum (equation (12)). This allows synthesizing the Cu@ PtNPs. In addition (equation (12)), the process of leaching copper from $\mathrm{Cu}-\mathrm{Pt}$ nanopowders by reaction (13) is used to increase the platinum content. The combination of concentrations of precursors and processes (equations (12) and (13)) allows controlling the composition of particles: $\mathrm{Cu}_{55} \mathrm{Pt}_{45}, \mathrm{Cu}_{25} \mathrm{Pt}_{75}$, and $\mathrm{Cu}_{42} \mathrm{Pt}_{58}$ :

$$
\begin{gathered}
\mathrm{Pt}(\mathrm{IV})+2 \mathrm{Cu} \longrightarrow 2 \mathrm{Cu}(\mathrm{II})+\mathrm{Pt} \\
\mathrm{Cu}+\frac{1}{2} \mathrm{O}_{2}+2 \mathrm{H}^{+} \longrightarrow \mathrm{Cu}^{2+}+\mathrm{H}_{2} \mathrm{O}
\end{gathered}
$$

Similarly, WCoNPs can be obtained using the electrochemical reduction of tungsten from the tungstate ion $\mathrm{WO}_{4}^{2-}$, which occurs due to catalysis by the citrate complex $\left[\mathrm{Co}(\mathrm{II})\left(\mathrm{C}_{6} \mathrm{H}_{5} \mathrm{O}_{7}\right) \mathrm{WO}_{2}\right]^{-}$(ads) formed during the sonoelectrolysis [68].

In the sonoelectrochemical syntheses of $M_{1} M_{2} N P s$ described in $[60,61,63,65-68]$, preferably the sizes of several nanometers are obtained. This is facilitated by the factor of alternate reduction of metals $\mathrm{M}_{1}$ and $\mathrm{M}_{2}$, that is, the deposition of each of them on a foreign surface. The synthesis is carried out mainly in solutions without surfactants (Table 2), and hence the products are obtained as agglomerates of $\mathrm{M}_{1} \mathrm{M}_{2} \mathrm{NPs}[56,60-67]$.

\section{Synthesis of Metallic Nanoparticles by Galvanic Replacement in Ultrasound Field}

The process of galvanic replacement (according to the generalized equation (14)) takes place via the electrochemical mechanism [69-72], where ionization of the sacrificial metal $M_{1}$ with "generation" of electrons (15) takes place at the anode areas and the reduction of $\mathrm{M}_{2}^{\mathrm{n}+}$ ions (16) occurs at the cathode sites:

$$
\begin{gathered}
\mathrm{mM}_{2}^{\mathrm{n}+}+\mathrm{nM}_{1} \longrightarrow \mathrm{nM}_{2}+\mathrm{nM}_{1}^{\mathrm{m}+} \\
\text { anode: } \mathrm{M}_{1} \longrightarrow \mathrm{M}_{1}^{\mathrm{m}+}+\mathrm{me}^{-} \\
\text {cathode: } \mathrm{M}_{2}^{n+}+\mathrm{ne}^{-} \longrightarrow \mathrm{M}_{2}
\end{gathered}
$$

Depending on the nature of the sacrificial metal pair "sacrificial $\left(M_{1}\right)$ - reduced $\left(M_{2}\right)$," the formation of sediments of the following three types is possible: the islands, the dendritic, and the film. The first two types are of the greatest interest for obtaining metal nanoparticles. The formation of "island" sediment occurs with a significant difference between the crystal lattices $M_{1}$ and $M_{2}$ and is realized according to the Volmer-Veber mechanism [75]. For example, the galvanic replacement of metals on the surfaces of magnesium [72] and silicon [71, 73] can be considered. The formation of dendritic sediment occurs at a high rate of the process (equation (14)), which is primarily due to the significant difference between the values of standard electrode potentials between $\mathrm{M}_{1}$ and $\mathrm{M}_{2}$ [72-75]. However, galvanic replacement is mainly used to extract metals from leaching solutions of ore and secondary raw materials. In the last decade, the galvanic replacement method has been intensively studied as effective for surface modification by metal nanoparticles and nanostructures [69-73].

The use of ultrasound significantly accelerates the rate of galvanic replacement, primarily due to the acceleration of the electron-generating reaction (equation (15)) because of the intensive renewal of the anode areas and the prevention of their passivation. Therefore, at the corresponding ultrasound parameters, as well as in solutions containing the surfactants, MNPs and $\mathrm{M}_{1} \mathrm{M}_{2} \mathrm{NPs}$ are obtained via the galvanic replacement technique (Table 3 ). In addition, ultrasound, by analogy with sonoelectrochemical syntheses, performs the function of "shaking" of MNPs from the cathode regions of the sacrificial metal. Surfactants, due to adsorption and formation of surface complexes with MNPs, inhibit their growth during the galvanic replacement and prevent the agglomeration of particles in solutions (Figure 9). Therefore, it is possible to obtain the MNPs with a small mean size (up to $10 \mathrm{~nm}$ ) and narrow size distribution. Specifically, the example of galvanic replacement of gold and platinum [78] showed that acoustic cavitation causes rapid nucleation, which contributes to the formation of a large number of MNPs with a uniform size distribution over a short period of time (usually several minutes). Simultaneously with ultrasound galvanic substitution, the formation of MNPs can also occur using the sonochemical reactions (4-6), since cavitation induces the formation of $\mathrm{H}$. and $\mathrm{HO}$ - and other secondary radicals that reduce metal ions in solutions. However, such parallel processes are not described in the literature. Using ultrasound galvanic replacement, stabilized MNPs were synthesized $(\mathrm{M}=\mathrm{Fe}, \mathrm{Co}, \mathrm{Sn}, \mathrm{Cu}, \mathrm{Ag}, \mathrm{Au}, \mathrm{Ru}, \mathrm{Pt})$ in PVP solutions [76, 78, 79]. Compact metal samples, among which the active ones such as magnesium, aluminum [79], 


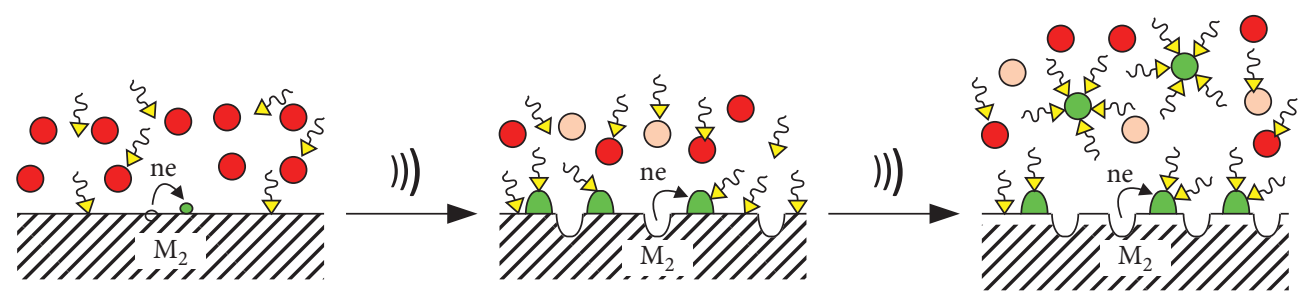

$\mathrm{A}$

$\mathrm{B}$

$\mathrm{C}$

$$
\begin{array}{lll} 
& -M_{1}^{+} & \xi \text { - Surfactant } \\
\bigcirc-M_{1} & \text { )) - Ultrasound } \\
& -M_{2}^{+} &
\end{array}
$$

FIGURE 9: Scheme of MNPs formation by galvanic replacement and ultrasound in solution with surfactant.
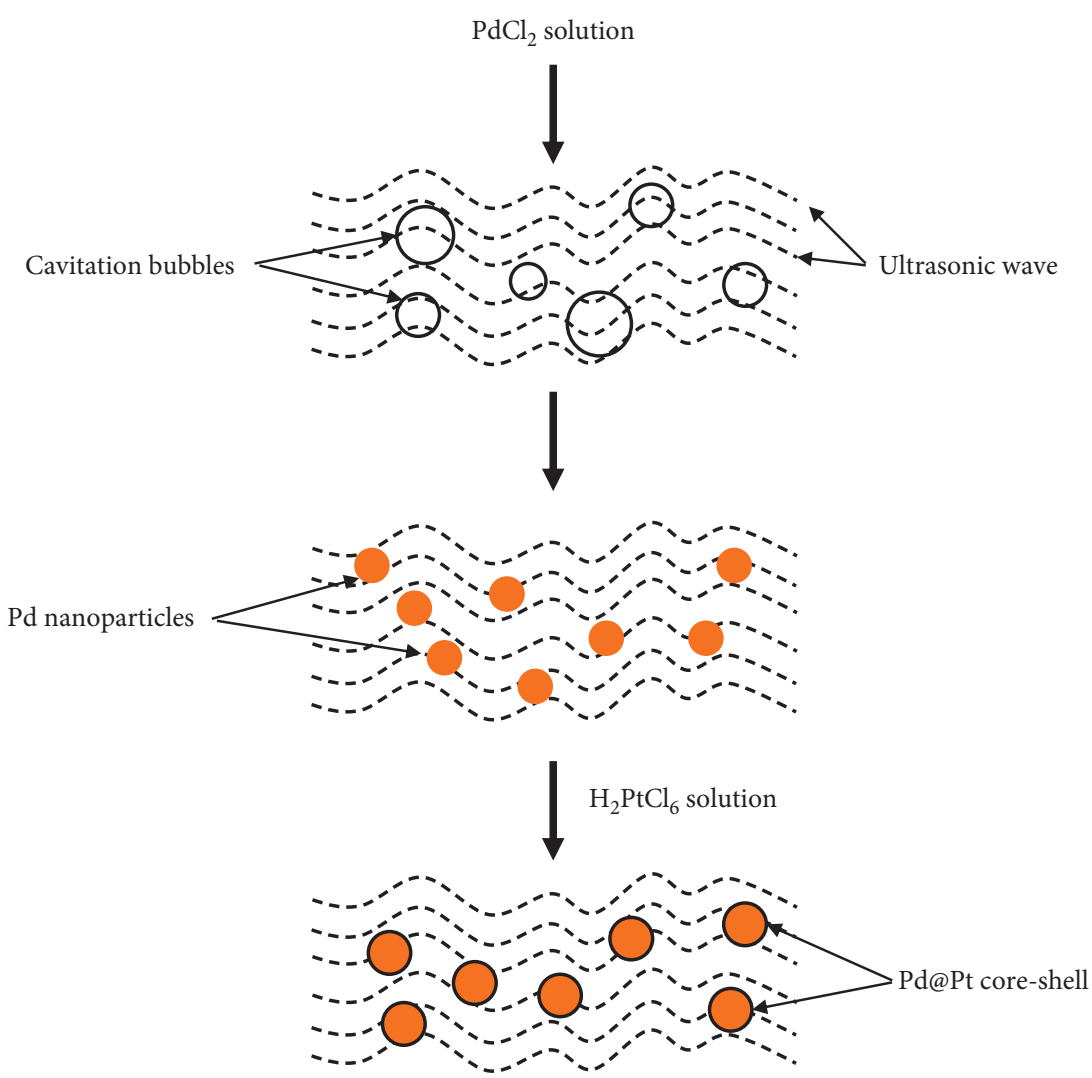

FIGURE 10: Schematic illustration for the synthesis of Pd@Pt core shell using ultrasonication. Reproduced from [86] under the terms of the Creative Commons CC BY license.

as well as iron [78], copper [76, 78], and silver [77], were used as sacrificial templates for the synthesis of nanoparticles.

In the literature, the ultrasound galvanic replacement techniques have been demonstrated for obtaining of core@ shell nanoparticles $\mathrm{M}_{1} @ \mathrm{M}_{2} \mathrm{NPs}[82,84,86]$ and nanoalloys $\mathrm{M}_{1} \mathrm{M}_{2} \mathrm{NPs}[80,81,83,85]$. In [86], a hybrid method of Pd@ Pt core-shell nanoparticles synthesis was proposed. In accordance with this method, the ultrasound is used for the realization of two successive processes: first is the sonochemical synthesis of $\mathrm{PdNPs}$ in $\mathrm{PdCl} 2$ solutions followed by the second one which is the galvanic substitution of platinum on the surface of palladium nanoparticles (Figure 10).

\section{Conclusions}

The combination of electrochemical reduction and ultrasonic field in aqueous solutions allows carrying out the controlled synthesis of metal nanoparticles with given geometry and bimetallic nanoparticles with controlled composition. Sonoelectrochemical synthesis, as a hybrid technique, is characterized by a high rate of nucleation and formation of MNPs and $\mathrm{M}_{1} \mathrm{M}_{2} \mathrm{NPs}$ with the minimum number of precursors and controllability. Therefore, it can be attributed to the "green" and promising technologies of nanomaterials production. The use of sacrificial anodes provides an algorithm "anodic dissolution-electrochemical 
reducing of metal-nucleation and growth of MNPs" which allows the design of nanoparticles.

Galvanic replacement under ultrasonic field in solutions containing the surfactants allows synthesizing stabilized MNPs. Sonogalvanic replacement is an effective method for obtaining nanoalloys $\left(\mathrm{M}_{1} \mathrm{M}_{2} \mathrm{NPs}\right)$ and core@shell nanoparticles $\left(M_{1} @ M_{2}\right)$. The processes at the anode and cathode areas of sacrificial metals in ultrasound are similar to the processes occurring at the sonoelectrochemical synthesis of MNPs due to the electrochemical nature of galvanic replacement.

\section{Abbreviations}

$\begin{array}{ll}\text { Ch: } & \text { Chitosan } \\ \text { CTAB: } & \text { Cetyltrimethylammonium bromide } \\ \text { DBDG: } & \text { Dibutyl diglyme } \\ \text { DPNs: } & \text { Dendritic particles nanostructures } \\ E^{0}: & \text { Standard electrode potential } \\ \mathrm{i}_{\text {cathode: }} & \text { Cathode current density } \\ \text { MNCs: } & \text { Metal nanoclusters } \\ \text { MNPs: } & \text { Metal nanoparticles } \\ \text { MPEO- } & \text { M a-Methoxy-x-mercapto-poly(ethylene } \\ \text { SH: } & \text { oxide) } \\ \text { NaPA: } & \text { Sodium polyacrylate } \\ \text { NTA: } & \left.\text { N(CH }{ }_{2} \text { COOH }\right)_{3} \text {, nitrilotriacetate } \\ \text { ORC: } & \text { Oxidation-reduction cycles } \\ \text { PDDA: } & \text { Polydiallyldimethylammonium chloride } \\ \text { PVA: } & \text { Polyvinyl alcohol } \\ \text { PVP: } & \text { Polyvinylpyrrolidone } \\ \text { SDS: } & \text { Sodium dodecyl sulfate } \mathrm{CH}_{3}\left(\mathrm{CH}_{2}\right)_{11} \mathrm{OSO}_{3} \mathrm{Na} \\ \text { THF: } & \text { Tetrahydrofuran } \\ \text { US: } & \text { Ultrasound. }\end{array}$

\section{Conflicts of Interest}

The authors declare that there are no conflicts of interest regarding the publication of this paper.

\section{Acknowledgments}

This work was carried out with the partial financial support of the National Research Foundation of Ukraine, Agreement 2020.02/0309 (no. 0120U105247: "Design of polyfunctional nanostructured mono- and bimetals with electrocatalytic and antimicrobial properties."

\section{References}

[1] B. Calderón-Jiménez, M. E. Johnson, A. R. Montoro Bustos, K. E. Murphy, M. R. Winchester, and J. R. Vega Baudrit, "Silver nanoparticles: technological advances, societal impacts, and metrological challenges," Frontiers in chemistry, vol. 5, p. 6, 2017.

[2] O. Gherasim, R. A. Puiu, A. C. Bîrcă, A.-C. Burduşel, and A. M. Grumezescu, "An updated review on silver nanoparticles in biomedicine," Nanomaterials, vol. 10, no. 11, Article ID 2318, 2020.

[3] N. Hlapisi, T. E. Motaung, L. Z. Linganiso, O. S. Oluwafemi, and S. P. Songca, "Encapsulation of gold nanorods with porphyrins for the potential treatment of cancer and bacterial diseases: a critical review," Bioinorganic Chemistry and Applications, vol. 2019, Article ID 7147128, 27 pages, 2019.

[4] X. Huang, Z. Li, Z. Yu, X. Deng, and Y. Xin, "Recent advances in the synthesis, properties, and biological applications of platinum nanoclusters," Journal of Nanomaterials, vol. 2019, Article ID 6248725, 2019.

[5] S. Gurunathan, M. Qasim, Y. Choi et al., "Antiviral potential of nanoparticles-can nanoparticles fight against coronaviruses?" Nanomaterials, vol. 10, no. 9, p. 1645, 2020.

[6] S. K. Kailasa, J. R. Koduru, M. L. Desai, T. J. Park, R. K. Singhal, and H. Basu, "Recent progress on surface chemistry of plasmonic metal nanoparticles for colorimetric assay of drugs in pharmaceutical and biological samples," TRAC Trends in Analytical Chemistry, vol. 105, pp. 106-120, 2018.

[7] Z. Liu, F. Zhao, S. Gao, J. Shao, and H. Chang, "The applications of gold nanoparticle-initialed chemiluminescence in biomedical detection," Nanoscale Research Letters, vol. 11, no. 1, p. 460, 2016.

[8] G. Shimoga, R. R. Palem, S.-H. Lee, and S.-Y. Kim, "Catalytic degradability of p-nitrophenol using ecofriendly silver nanoparticles," Metals, vol. 10, no. 12, Article ID 1661, 2020.

[9] S. Jadoun, R. Arif, N. K. Jangid, and R. K. Meena, "Green synthesis of nanoparticles using plant extracts: a review," Environmental Chemistry Letters, vol. 19, no. 1, pp. 355-374, 2021.

[10] H. Bahrulolum, S. Nooraei, N. Javanshir et al., "Green synthesis of metal nanoparticles using microorganisms and their application in the agrifood sector," Journal of Nanobiotechnology, vol. 19, no. 1, pp. 1-26, 2021.

[11] V. V. Yanilkin, G. R. Nasretdinova, and V. A. Kokorekin, "Mediated electrochemical synthesis of metal nanoparticles," Russian Chemical Reviews, vol. 87, no. 11, pp. 1080-1110, 2018.

[12] M. Izzi, M. C. Sportelli, N. Ditaranto et al., "Pros and cons of sacrificial anode electrolysis for the preparation of transition metal colloids: a review," ChemElectroChem, vol. 7, no. 2, pp. 386-394, 2020.

[13] O. I. Kuntyi, A. R. Kytsya, A. B. Bondarenko, A. S. Mazur, I. P. Mertsalo, and L. I. Bazylyak, "Microplasma synthesis of silver nanoparticles in PVP solutions using sacrificial silver anodes," Colloid \& Polymer Science, vol. 299, no. 5, pp. 855-863, 2021.

[14] B. G. Pollet, "The use of ultrasound for the fabrication of fuel cell materials," International Journal of Hydrogen Energy, vol. 35, no. 21, pp. 11986-12004, 2010.

[15] V. Sáez and T. Mason, "Sonoelectrochemical synthesis of nanoparticles," Molecules, vol. 14, no. 10, pp. 4284-4299, 2009.

[16] P. Sakkas, O. Schneider, S. Martens, P. Thanou, G. Sourkouni, and C. Argirusis, "Fundamental studies of sonoelectrochemical nanomaterials preparation," Journal of Applied Electrochemistry, vol. 42, no. 9, pp. 763-777, 2012.

[17] M. Hujjatul Islam, M. T. Y. Paul, O. S. Burheim, and B. G. Pollet, "Recent developments in the sonoelectrochemical synthesis of nanomaterials," Ultrasonics Sonochemistry, vol. 59, Article ID 104711, 2019.

[18] Z. Li, T. Zhuang, J. Dong et al., "Sonochemical fabrication of inorganic nanoparticles for applications in catalysis," Ultrasonics Sonochemistry, vol. 71, Article ID 105384, 2021.

[19] K.-H. Huynh, X.-H. Pham, J. Kim et al., "Synthesis, properties, and biological applications of metallic alloy nanoparticles," International Journal of Molecular Sciences, vol. 21, no. 14, Article ID 5174, 2020. 
[20] J. Theerthagiri, J. Madhavan, S. J. Lee, M. Y. Choi, M. Ashokkumar, and B. G. Pollet, "Sonoelectrochemistry for energy and environmental applications," Ultrasonics Sonochemistry, vol. 63, Article ID 104960, 2020.

[21] J. M. Costa and A. F. d. Almeida Neto, "Ultrasound-assisted electrodeposition and synthesis of alloys and composite materials: a review," Ultrasonics Sonochemistry, vol. 68, Article ID 105193, 2020.

[22] R. G. Compton, J. C. Eklund, and F. Marken, "Sonoelectrochemical processes: a review," Electroanalysis, vol. 9, no. 7, pp. 509-522, 1997.

[23] A. Mallik and B. C. Ray, "Implication of low temperature and sonication on electrocrystallization mechanism of $\mathrm{Cu}$ thin films: a kinetics and structural correlation," Materials Research, vol. 16, no. 2, pp. 539-545, 2013.

[24] I. Tudela, Y. Zhang, M. Pal, I. Kerr, T. J. Mason, and A. J. Cobley, "Ultrasound-assisted electrodeposition of nickel: effect of ultrasonic power on the characteristics of thin coatings," Surface and Coatings Technology, vol. 264, pp. 49-59, 2015.

[25] A. Nevers, L. Hallez, F. Touyeras, and J.-Y. Hihn, "Effect of ultrasound on silver electrodeposition: crystalline structure modification," Ultrasonics Sonochemistry, vol. 40, pp. 60-71, 2018.

[26] S. Boopathi and S. S. Kumar, "Impact of ultrasonic waves in direct electrodeposition of nanostructured AuPt alloy catalyst on carbon substrate: structural characterization and its superior electrocatalytic activity for methanol oxidation reaction," Journal of Physical Chemistry C, vol. 118, no. 51, pp. 29866-29873, 2014.

[27] P. Sriram, M. K. Kumar, G. T. Selvi, N. S. Jha, N. Mohanapriya, and S. K. Jha, "Elucidation of ultrasonic wave-assisted electrodeposited AgPd nanoalloy from ionic liquid as an efficient bifunctional electrocatalyst for methanol oxidation and hydrogen peroxide reduction," Electrochimica Acta, vol. 323, Article ID 134809, 2019.

[28] M. Riđošić, E. García-Lecina, A. Salicio-Paz, and J. Bajat, "The advantage of ultrasound during electrodeposition on morphology and corrosion stability of Zn-Co alloy coatings," Transactions of the IMF, vol. 98, no. 3, pp. 114-120, 2020.

[29] I. Tudela, Y. Zhang, M. Pal, I. Kerr, and A. J. Cobley, "Ultrasound-assisted electrodeposition of composite coatings with particles," Surface and Coatings Technology, vol. 259, pp. 363-373, 2014.

[30] M. Murtaza, N. Hussain, H. Ya, and H. Wu, "High purity copper nanoparticles via sonoelectrochemical approach," Materials Research Express, vol. 6, no. 11, Article ID 115058, 2019.

[31] I. Haas, S. Shanmugam, and A. Gedanken, "Synthesis of copper dendrite nanostructures by a sonoelectrochemical method," Chemistry - A European Journal, vol. 14, no. 15, pp. 4696-4703, 2008.

[32] V. N. Shut and S. E. Mozzharov, "Properties of ultrafine copper-containing powders prepared by a sonoelectrochemical method," Inorganic Materials, vol. 53, no. 8, pp. 883-889, 2017.

[33] I. Haas, S. Shanmugam, and A. Gedanken, "Pulsed sonoelectrochemical synthesis of size-controlled copper nanoparticles stabilized by poly(N-vinylpyrrolidone)," The Journal of Physical Chemistry B, vol. 110, no. 34, pp. 16947-16952, 2006.

[34] J. Zhu, S. Liu, O. Palchik, Y. Koltypin, and A. Gedanken, "Shape-controlled synthesis of silver nanoparticles by pulse sonoelectrochemical methods," Langmuir, vol. 16, no. 16, pp. 6396-6399, 2000.

[35] J.-J. Zhu, Q.-F. Qiu, H. Wang, J.-R. Zhang, J.-M. Zhu, and Z.-Q. Chen, "Synthesis of silver nanowires by a sonoelectrochemical method," Inorganic Chemistry Communications, vol. 5, no. 4, pp. 242-244, 2002.

[36] Y. Socol, O. Abramson, A. Gedanken, Y. Meshorer, L. Berenstein, and A. Zaban, "Suspensive electrode formation in pulsed sonoelectrochemical synthesis of silver nanoparticles," Langmuir, vol. 18, no. 12, pp. 4736-4740, 2002.

[37] L.-P. Jiang, A.-N. Wang, Y. Zhao, J.-R. Zhang, and J.-J. Zhu, "A novel route for the preparation of monodisperse silver nanoparticles via a pulsed sonoelectrochemical technique," Inorganic Chemistry Communications, vol. 7, no. 4, pp. 506509,2004

[38] Y.-C. Liu and L.-H. Lin, "New pathway for the synthesis of ultrafine silver nanoparticles from bulk silver substrates in aqueous solutions by sonoelectrochemical methods," Electrochemistry Communications, vol. 6, no. 11, pp. 1163-1168, 2004.

[39] S. Tang, X. Meng, H. Lu, and S. Zhu, "PVP-assisted sonoelectrochemical growth of silver nanostructures with various shapes," Materials Chemistry and Physics, vol. 116, no. 2-3, pp. 464-468, 2009.

[40] L. V. Vu, N. N. Long, S. C. Doanh, and B. Q. Trung, "Preparation of silver nanoparticles by pulse sonoelectrochemical method and studying their characteristics," Journal of Physics: Conference Series, vol. 187, no. 1, Article ID 012077, 2009.

[41] O. Kuntyi, M. Shepida, M. Sozanskyi et al., "Sonoelectrochemical synthesis of silver nanoparticles in sodium polyacrylate solution," Biointerface Research in Applied Chemistry, vol. 11, no. 4, pp. 12202-12214, 2020.

[42] M. Shepida, O. Kuntyi, M. Sozanskyi, and Y. Sukhatskiy, "Sonoelectrochemical synthesis of antibacterial active silver nanoparticles in Rhamnolipid solution," Advances in Materials Science and Engineering, vol. 2021, pp. 1-9, 2021.

[43] A. Aqil, H. Serwas, J. L. Delplancke, R. Jérôme, C. Jérôme, and L. Canet, "Preparation of stable suspensions of gold nanoparticles in water by sonoelectrochemistry," Ultrasonics Sonochemistry, vol. 15, no. 6, pp. 1055-1061, 2008.

[44] Q. Shen, Q. Min, J. Shi, L. Jiang, W. Hou, and J.-J. Zhu, "Synthesis of stabilizer-free gold nanoparticles by pulse sonoelectrochemical method," Ultrasonics Sonochemistry, vol. 18, no. 1, pp. 231-237, 2011.

[45] Y.-C. Liu, L.-H. Lin, and W.-H. Chiu, "Size-controlled synthesis of gold nanoparticles from bulk gold substrates by sonoelectrochemical methods," The Journal of Physical Chemistry B, vol. 108, no. 50, pp. 19237-19240, 2004.

[46] K.-L. Ou, K.-H. Yang, Y.-C. Liu, T.-C. Hsu, and Q.-Y. Chen, "New strategy to prepare enriched and small gold nanoparticles by sonoelectrochemical pulse methods," Electrochimica Acta, vol. 58, pp. 497-502, 2011.

[47] K.-H. Yang, Y.-C. Liu, T.-C. Hsu, and H.-I. Tsai, "pH-insensitive fabrication of gold nanoparticles with high concentration by ultrasound-assisted electrochemical process via aid of chitosan," Materials Research Bulletin, vol. 45, no. 1, pp. 63-68, 2010.

[48] K.-L. Ou, C.-C. Yu, Y.-C. Liu, K.-H. Yang, C.-C. Wang, and Q.-Y. Chen, "Sonoelectrochemical synthesis of chitosan/gold nanocomposites for application in removing toxic materials in mainstream smokes," Materials Research Bulletin, vol. 46, no. 12, pp. 2333-2337, 2011. 
[49] K.-L. Ou, T.-C. Hsu, Y.-C. Liu, and K.-H. Yang, “Controllably catalytic decomposition of acetaldehyde in solution by using gold nanoparticles released from sonoelectrochemically prepared gold microsheets," Journal of Electroanalytical Chemistry, vol. 701, pp. 25-31, 2013.

[50] X.-F. Qiu, J.-Z. Xu, J.-M. Zhu, J.-J. Zhu, S. Xu, and H.-Y. Chen, "Controllable synthesis of palladium nanoparticles via a simple sonoelectrochemical method," Journal of Materials Research, vol. 18, no. 6, pp. 1399-1404, 2003.

[51] Q. Shen, Q. Min, J. Shi et al., "Morphology-controlled synthesis of palladium nanostructures by sonoelectrochemical method and their application in direct alcohol oxidation," Journal of Physical Chemistry C, vol. 113, no. 4, pp. 1267-1273, 2009.

[52] Q. Shen, L. Jiang, H. Zhang, Q. Min, W. Hou, and J.-J. Zhu, "Three-dimensional dendritic Pt nanostructures: sonoelectrochemical synthesis and electrochemical applications," Journal of Physical Chemistry C, vol. 112, no. 42, pp. 1638516392, 2008.

[53] V. Zin, B. G. Pollet, and M. Dabalà, "Sonoelectrochemical (20 $\mathrm{kHz}$ ) production of platinum nanoparticles from aqueous solutions," Electrochimica Acta, vol. 54, no. 28, pp. 7201-7206, 2009.

[54] A. Khachatryan, R. Sarkissyan, L. Hassratyan, and V. Khachatryan, "Influence of ultrasound on nanostructural iron formed by electrochemical reduction," Ultrasonics Sonochemistry, vol. 11, no. 6, pp. 405-408, 2004.

[55] A. Iranzo, F. Chauvet, and T. Tzedakis, "Synthesis of submicrometric dendritic iron particles in an Electrochemical and Vibrating Hele-Shaw cell: study of the growth of ramified branches," Electrochimica Acta, vol. 250, pp. 348-358, 2017.

[56] J.-L. Delplancke, J. Dille, J. Reisse, G. J. Long, A. Mohan, and F. Grandjean, "Magnetic nanopowders: ultrasound-assisted electrochemical preparation and properties," Chemistry of Materials, vol. 12, no. 4, pp. 946-955, 2000.

[57] H. Lei, Y.-J. Tang, J.-J. Wei, J. Li, X.-B. Li, and H.-L. Shi, "Synthesis of tungsten nanoparticles by sonoelectrochemistry," Ultrasonics Sonochemistry, vol. 14, no. 1, pp. 81-83, 2007.

[58] I. Haas and A. Gedanken, "Synthesis of metallic magnesium nanoparticles by sonoelectrochemistry," Chemical Communications, vol. 15, no. 15, pp. 1795-1797, 2008.

[59] C. Mahendiran, R. Ganesan, and A. Gedanken, "Sonoelectrochemical synthesis of metallic aluminum nanoparticles," European Journal of Inorganic Chemistry, vol. 2009, no. 14, pp. 2050-2053, 2009.

[60] V. Mancier, J.-L. Delplancke, J. Delwiche et al., "Morphologic, magnetic, and Mössbauer spectral properties of $\mathrm{Fe}_{75} \mathrm{Co}_{25}$ nanoparticles prepared by ultrasound-assisted electrochemistry," Journal of Magnetism and Magnetic Materials, vol. 281, no. 1, pp. 27-35, 2004.

[61] M. Dabalà, B. G. Pollet, V. Zin, E. Campadello, and T. J. Mason, "Sonoelectrochemical $(20 \mathrm{kHz})$ production of $\mathrm{Co}_{65} \mathrm{Fe}_{35}$ alloy nanoparticles from Aotani solutions," Journal of Applied Electrochemistry, vol. 38, no. 3, pp. 395-402, 2008.

[62] V. Zin and M. Dabalà, "Temperature dependent properties and aggregation behaviour of FeCo nanoparticles produced sonoelectrochemically," Journal of Nanoparticle Research, vol. 13, no. 12, pp. 7253-7262, 2011.

[63] V. Zin and M. Dabalà, "Iron-chromium alloy nanoparticles produced by pulsed sonoelectrochemistry: synthesis and characterization," Acta Materialia, vol. 58, no. 1, pp. 311-319, 2010 .
[64] V. Zin, K. Brunelli, and M. Dabalà, "Characterization of $\mathrm{Cu}-\mathrm{Ni}$ alloy electrodeposition and synthesis of nanoparticles by pulsed sonoelectrochemistry," Materials Chemistry and Physics, vol. 144, no. 3, pp. 272-279, 2014.

[65] S. Levi, V. Mancier, C. Rousse et al., "Synthesis of spherical copper-platinum nanoparticles by sonoelectrochemistry followed by conversion reaction," Electrochimica Acta, vol. 176, pp. 567-574, 2015.

[66] M. Guzman, J.-L. Delplancke, G. J. Long, J. Delwiche, M.-J. Hubin-Franskin, and F. Grandjean, "Morphologic and magnetic properties of $\mathrm{Pd}_{100-\mathrm{x}} \mathrm{Fe}_{\mathrm{x}}$ nanoparticles prepared by ultrasound assisted electrochemistry," Journal of Applied Physics, vol. 92, no. 5, pp. 2634-2640, 2002.

[67] Y.-C. Liu, H.-T. Lee, and H.-H. Peng, "New pathway for sonoelectrochemical synthesis of gold-silver alloy nanoparticles from their bulk substrates," Chemical Physics Letters, vol. 400, no. 4-6, pp. 436-440, 2004.

[68] R. Plaipaitè-Nalivaiko, E. Griškonis, D. Adlienè, and L. Gilys, "Continuous ultrasound assisted sonoelectrochemical synthesis of W-Co alloy nanoparticles," Acta Physica Polonica A, vol. 136, no. 2, pp. 267-273, 2019.

[69] A. Lahiri, G. Pulletikurthi, and F. Endres, "A review on the electroless deposition of functional materials in ionic liquids for batteries and catalysis," Frontiers in chemistry, vol. 7, p. 85, 2019.

[70] A. Papaderakis, I. Mintsouli, J. Georgieva, and S. Sotiropoulos, "Electrocatalysts prepared by galvanic replacement," Catalysts, vol. 7, no. 12, p. 80, 2017.

[71] O. I. Kuntyi, G. I. Zozulya, M. V. Shepida, and S. I. Nichkalo, "Deposition of nanostructured metals on the surface of silicon by galvanic replacement: a mini-review," Voprosy khimii $i$ khimicheskoi tekhnologii, vol. 3, no. 3, pp. 74-82, 2019.

[72] O. I. Kuntyi, G. I. Zozulya, and M. V. Shepida, "Nanoscale galvanic replacement in non-aqueous media: a mini review," Voprosy khimii i khimicheskoi tekhnologii, vol. 4, no. 4, pp. 5-15, 2020.

[73] M. Shepida, O. Kuntyi, G. Zozulya, and E. Kaniukov, "Deposition of palladium nanoparticles on the silicon surface via galvanic replacement in DMSO," Applied Nanoscience, vol. 10, no. 8, pp. 2563-2568, 2020.

[74] O. I. Kuntyi, O. B. Masyk, and R. V. Minakova, "Morphology of nickel powder contactly precipitated on magnesium in aqueous solutions," Materials Science, vol. 40, no. 3, pp. 428-432, 2004.

[75] K.-Y. Niu, S. A. Kulinich, J. Yang, A. L. Zhu, and X.-W. Du, "Galvanic replacement reactions of active-metal nanoparticles," Chemistry - A European Journal, vol. 18, no. 14, pp. 4234-4241, 2012.

[76] J. Liu, M. Hu, Y. Song, F. Wang, J. Ji, and Z. Li, “A novel strategy to prepare silver nanoparticles by ethanol-induced shape conversion of silver dendrites from modified galvanic replacement," Synthetic Metals, vol. 187, pp. 185-192, 2014.

[77] P. Pienpinijtham, P. Sornprasit, K. Wongravee, C. Thammacharoen, and S. Ekgasit, "Gold microsheets having nano/microporous structures fabricated by ultrasonic-assisted cyclic galvanic replacement," RSC Advances, vol. 5, no. 95, pp. 78315-78323, 2015.

[78] C. Wu, B. P. Mosher, and T. Zeng, "Rapid synthesis of gold and platinum nanoparticles using metal displacement reduction with sonomechanical assistance," Chemistry of $\mathrm{Ma}$ terials, vol. 18, no. 13, pp. 2925-2928, 2006.

[79] C. Wu, B. P. Mosher, and T. Zeng, "Chemically-mechanically assisted synthesis of metallic and oxide nanoparticles in 
ambient conditions," Journal of Nanoscience and Nanotechnology, vol. 8, no. 1, pp. 386-389, 2008.

[80] V. Mancier, C. Rousse-Bertrand, J. Dille, J. Michel, and P. Fricoteaux, "Sono and electrochemical synthesis and characterization of copper core-silver shell nanoparticles," Ultrasonics Sonochemistry, vol. 17, no. 4, pp. 690-696, 2010.

[81] C. Rousse, J. Josse, V. Mancier, S. Levi, S. C. Gangloff, and P. Fricoteaux, "Synthesis of copper-silver bimetallic nanopowders for a biomedical approach; study of their antibacterial properties," RSC Advances, vol. 6, no. 56, pp. 50933-50940, 2016.

[82] M. Farsadrooh, M. Noroozifar, A. R. Modarresi-Alam, and H. Saravani, "Sonochemical synthesis of high-performance Pd@CuNWs/MWCNTs-CH electrocatalyst by galvanic replacement toward ethanol oxidation in alkaline media," $U l$ trasonics Sonochemistry, vol. 51, pp. 478-486, 2019.

[83] A. S. Douk, H. Saravani, M. Farsadrooh, and M. Noroozifar, "An environmentally friendly one-pot synthesis method by the ultrasound assistance for the decoration of ultrasmall PdAg NPs on graphene as high active anode catalyst towards ethanol oxidation," Ultrasonics Sonochemistry, vol. 58, Article ID 104616, 2019.

[84] E. Lee, J.-H. Jang, M. A. Matin, and Y.-U. Kwon, “One-step sonochemical syntheses of Ni@Pt core-shell nanoparticles with controlled shape and shell thickness for fuel cell electrocatalyst," Ultrasonics Sonochemistry, vol. 21, no. 1, pp. 317-323, 2014.

[85] Z. Sun, J. Masa, W. Xia et al., "Rapid and surfactant-free synthesis of bimetallic $\mathrm{Pt}-\mathrm{Cu}$ nanoparticles simply via ultrasound-assisted redox replacement," ACS Catalysis, vol. 2, no. 8, pp. 1647-1653, 2012.

[86] H. Zheng, M. S. Matseke, and T. S. Munonde, "The unique $\mathrm{Pd} @ \mathrm{Pt} / \mathrm{C}$ core-shell nanoparticles as methanol-tolerant catalysts using sonochemical synthesis," Ultrasonics Sonochemistry, vol. 57, pp. 166-171, 2019. 